\title{
Does derivatives use reduce the cost of equity?
}

\author{
Shamim Ahmed* \\ Amrit Judge ${ }^{\dagger}$ \\ Syed Ehsan Mahmud $\$$
}

July 3, 2018

\begin{abstract}
This paper examines the impact of hedging on the cost of equity capital. Using handcollected data on derivatives use for a sample of German non-financial firms, we find that user firms have a 109 basis point lower industry-adjusted cost of equity than non-users. This reduction in the cost of equity of users is attributable to their lower market, size, and value risk factor exposures. The observed negative relation between derivatives use and the cost of equity remains robust to specifications that account for potential endogeneity arising from a firm's derivatives hedging and capital structure decisions. We find that the reduction in the cost of equity is largest for smaller firms and for firms making use of foreign currency and interest rate derivatives. Moreover, new derivatives users experience a significant reduction in the cost of equity in the first year of adoption. Finally, using expected default frequency data, we show direct evidence that firms' derivatives use reduces financial distress risk.
\end{abstract}

JEL Classification: G12, G13, and G32

Keywords: Derivatives, Risk management, Asset pricing, Financial distress risk.

\footnotetext{
* Corresponding author. Nottingham University Business School, University of Nottingham, Nottingham, NG8 1BB, United Kingdom; shamim.ahmed@nottingham.ac.uk. Tel.: +44 (0) 115823 2359. Fax: +44 (0) 115846 6667.

${ }^{\dagger}$ Nottingham University Business School, University of Nottingham, Nottingham, NG8 1BB, United Kingdom; amrit.judge@nottingham.ac.uk.

${ }^{\ddagger}$ Nottingham University Business School, University of Nottingham, Nottingham, NG8 1BB, United Kingdom; syed.mahmud@nottingham.ac.uk.

${ }^{\S}$ We acknowledge support from Moody's Analytics for providing the expected default frequency data. We are also grateful to Brian Lucey (the editor) and two anonymous referees for useful comments and suggestions.
} 


\section{Introduction}

The classic capital structure theory of Modigliani and Miller (1958) implies that corporate financial activities like hedging are irrelevant if investors (shareholders) can replicate these activities by themselves. In practice, however, the use of derivative instruments for active corporate risk management has grown rapidly in recent years (Bartram, Brown, and Fehle, 2009; Campello, Lin, Ma, and Zou, 2011; Chen and King, 2014). For example, a survey by the International Swaps and Derivatives Association in 2009 reports that about $94 \%$ of Fortune Global 500 companies across 32 countries use derivatives to hedge their business and financial risks. In view of this observation, one of the important questions from both an academic and practitioner perspective is whether derivatives users experience a lower cost of equity capital than do non-users. Using a sample of non-financial firms in the United States (US), Gay, Lin, and Smith (2011) provide evidence that the cost of equity of derivatives users is lower than non-users. However, little is known about whether such relationship holds outside of the US, especially in countries where firms face greater exposures to financial price uncertainty, such as foreign exchange rate risk, and/or different regulatory and institutional environments. The ultimate benefit of derivative-related activities in terms of a lower cost of equity capital may not materialize for firms in other countries and knowing this is important in view of the fact that an increasing amount of corporate resources are expended in pursuing such activities.

In this paper, our main goal is to investigate the impact of derivatives activities on firms' cost of equity capital by utilizing hand-collected data comprising financial derivative instruments usage by a sample of German non-financial firms. Specifically, we compute the relative cost of equity of users and non-users and analyze the source of any difference between the two groups if it exists. We next explore whether firm size and type of derivatives matter in the relation between derivatives use and the cost of equity capital. In addition, we examine whether there is any significant change in the cost of equity experienced by firms that were non-users of derivative instruments and later initiated derivatives programs for risk management purpose. Finally, using a firm's probability of default, we explore whether hedging reduces financial distress risk.

Our choice of a sample of German firms is due to several reasons. First, Germany represents one of the largest stock markets, by market capitalization, in the world outside of the US. Second, according to the World Bank, at the end of December 2016, German firms export more than their US counterparts, which exposes them to higher levels of foreign exchange rate risk. Consistent with this observation, Bodnar and Gebhardt (1999) find that a higher proportion of German firms compared to US firms use derivative instruments. Consequently, it is likely that German firms experience a larger impact of derivatives use on their cost of equity capital than 
those in the US. Third, institutional characteristics in Germany are considerably different from those in the US. For example, in Table 1, we present some key institutional characteristics of Germany and US. From columns 1 and 2, it can be seen that German firms are less widely held, which implies a predominance of blockholder ownership structure. On the one hand, this can lower the cost of equity following the argument of Shleifer and Vishny (1997) that blockholders have greater incentives to monitor a firm's management in an unbiased way and thereby leading to a reduction of agency costs and a lower cost of equity. On the other hand, the cost of equity rises in the presence of large blockholders due to their extraction of private benefits of control (Ashbaugh, Collins, and LaFond, 2004). Because of these two competing views, it is unclear what would be the ultimate impact of derivatives use on the cost of equity in the presence of a concentrated ownership structure. We see in columns 3 and 4 that shareholders in Germany have lower levels of rights and right enforcement than those in the US. In the absence of higher levels of shareholder rights and right enforcement, the likelihood of an out-of-court reorganization of the firm is very low (La Porta, Lopez-de-Silanes, Shleifer, and Vishny, 1998). As a result, the cost of equity capital for German firms are likely to be higher (Hail and Leuz, 2006), which suggests larger potential benefits from the use of derivatives in terms of cost of equity reduction.

Table 1 also shows that financial transparency in Germany is much lower due to less stringent equity disclosure requirements by the Federal Financial Supervisory Authority (see column 5). A lower level of financial transparency increases out-of-pocket monitoring costs borne by shareholders, which in turn increases the cost of equity capital (Hail and Leuz, 2006; Lombardo and Pagano, 2002). Looking at column 6, we see that firms in Germany face higher corporate effective tax rates than firms in the US. In the presence of financial market frictions, taxation allows a firm to achieve tax-shield benefits from debt financing. Hence, firms in Germany are likely to be more leveraged and therefore face greater financial distress risk. The use of derivative instruments is then expected to reduce the cost of equity to a greater extent. German firms also experience a lower level of bankruptcy efficiency (see column 7). In this connection, Davydenko and Franks (2008) note that borrowing from multiple banks is much more common for German firms due to a bank-oriented financial system. As a result, the direct bankruptcy costs associated with debt renegotiation at the time of default is higher and the renegotiation process is more difficult, both of which reduce the terminal value of a firm in bankruptcy. In such case, it is likely that shareholders would require additional risk premiums for bearing higher financial distress risk than those in a market-oriented financial system. Therefore, in a German setting we would expect a larger impact of derivatives use in reducing the cost of equity. The last column of Table 1 shows that the block premium is considerably higher for 
firms in Germany. This implies a higher level of private benefits of control by blockholders and a consequent agency problem between blockholders and minority/retail shareholders. In such case, the use of derivatives is expected to cause a larger reduction in the cost of equity capital. Taken together, all of the above attributes make Germany an interesting laboratory to examine the relation between firms' derivatives use and the cost of equity capital.

We compute an estimate of a firm's cost of equity based on the Fama and French (1993) threefactor model. Our empirical evidence suggests that hedging through derivatives significantly reduces the cost of equity capital. In univariate analysis, we find that firms using derivatives have, on average, a 306 basis point lower cost of equity than non-users. Employing an industryadjusted estimate, user firms have, on average, a 109 basis point lower cost of equity than nonusers. We also find evidence that derivatives user firms have significantly lower Fama and French (1993) three-factor betas than do non-user firms. Specifically, user firms have, on average, a $27.22 \%$ lower market factor beta, a $42.38 \%$ lower small-minus-big size (SMB) factor beta, and a $16.14 \%$ lower high-minus-low value (HML) factor beta than non-users. In conjunction with the corresponding positive factor risk premium estimates, these reductions in betas suggest that the lower cost of equity of derivatives users is driven by their lower exposures to the market, SMB, and HML risk factors. Fama and French (1996) and Vassalou and Xing (2004) provide evidence that the SMB and HML factors contain information regarding a firm's default risk. Hence, our empirical results on the contributions of the SMB and HML betas to the reductions in the cost of equity of user firms is consistent with the notion that hedging through derivatives is linked with the mitigation of financial distress risk, which in turn leads to lower SMB and HML factor exposures. Campbell, Hilscher, and Szilagyi (2008), however, show that although financially distressed firms have higher SMB and HML factor exposures, they can also have lower average stock returns when compared to less distressed firms. This casts doubt on the distress risk representation of the Fama and French (1993) three-factor model and therefore our reasoning that firm's derivatives use is associated with a lowering of financial distress risk proxied by the SMB and HML factors. To address this concern, we utilize a firm's expected default frequency $(\mathrm{EDF})$ as a proxy for financial distress risk and investigate the impact of derivatives use on the probability of default. The results from this empirical exercise confirm that financial hedging activities do indeed reduce financial distress risk.

Consistent with the findings of the univariate analysis, our results from the pooled regressions show that derivatives users experience a significantly lower cost of equity than non-users. One concern regarding the pooled regressions is that the results could be spurious due to potential endogeneity arising from a firm's financial hedging and capital structure decisions. We address 
this concern by examining firms' cost of equity, derivatives use, and leverage decisions within a simultaneous equations framework and find a significantly negative relation between derivatives use and the cost of equity capital. This suggests that the observed impact of financial hedging activities on the cost of equity cannot be attributed to endogeneity. As a further robustness check, we conduct a propensity score matching analysis. The results show that derivatives user firms have, on average, a 111 (75) basis point lower cost of equity (industry-adjusted cost of equity) than non-user matched firms. Our empirical analysis using the pooled regressions also reveals that the reduction in the cost of equity capital is largest for smaller firms. A similar finding emerges for firms making use of foreign currency and interest rate derivative instruments. Lastly, we find that new user firms experience a reduction in the cost of equity of 246 basis points in the first year of adoption. The average reduction in the industry-adjusted cost of equity also remains markedly high at 286 basis points. Notably, these reductions in the cost of equity capital of new users stem from their lower market, size, and value risk factor exposures.

The main contribution of our paper is to shed light on the potential benefits of risk management through financial hedging for corporations in a country like Germany, which is largely characterized by an insider system of corporate governance and bank dominated financing. In other words, our examination of the impact of derivatives use on the cost of equity for German non-financial firms provides useful insights to corporations operating in Germany and in countries alike, in terms of institutional settings, that may consider using derivatives as a means of lowering their cost of financing capital. Another contribution of this paper is by utilizing data on EDF we show directly whether German non-financial firms' derivatives use significantly reduces the likelihood of financial distress. It is worth highlighting that empirical studies on the impact of hedging activities on financial distress risk focus almost exclusively on US firms.

The paper related to ours is Gay, Lin, and Smith (2011), who investigate a sample of US non-financial firms and find that the cost of equity of derivatives user firms is lower than non-users by 24 to 78 basis points. The authors also find that the reduction in the cost of equity is attributable to lower market and SMB factor betas. Smaller firms and firms that use foreign currency and interest rate derivatives experience the largest reductions in the cost of equity. Although our empirical results are qualitatively similar to those in Gay, Lin, and Smith (2011), we find a larger impact of derivatives use in reducing the cost of equity capital in a German setting. In addition, we show directly that firms' derivatives activities significantly lower the likelihood of financial distress - evidence that is missing in the aforementioned paper. Another important paper related to ours is Campello, Lin, Ma, and Zou (2011). They show that derivatives users pay lower interest spreads than non-users and are less likely to have capital 
expenditure restrictions in their loan agreements. Recently, Chen and King (2014) examine the impact of corporate hedging activities on the cost of public debt and provide evidence that derivatives use is associated with a lower cost of debt. A common finding of all these empirical studies is that the use of derivatives significantly reduces a firm's cost of capital.

Our paper also adds to an extant literature on financial hedging and corporate valuation. Allayannis and Weston (2001) examine the effect of financial hedging on a sample of US firms and find foreign currency derivatives use is associated with a $4.87 \%$ increase in firm value. Using a sample of firms in the US airline industry, Carter, Rogers, and Simkins (2006) also find that hedging increases firm value by as much as 10\%. Allayannis, Lel, and Miller (2012) find evidence that the use of foreign currency derivatives increases firm value in the presence of a strong governance structure. Further, Pérez-González and Yun (2013) find that hedging increases firm value. Jin and Jorion (2006), however, provide empirical evidence that hedging does not affect the market value of firms operating in the US oil and gas industry. Similarly, Fauver and Naranjo (2010) find a significantly negative relation between derivatives use and firm value in the presence of greater agency and monitoring problems. We complement and extend this line of literature by empirically investigating the impact of financial derivatives hedging on the cost of equity capital outside of the US.

The remainder of this paper is organized as follows. Section 2 describes the data collection process and the construction of hedging variables and risk factors and outlines the methodology. Section 3 summarizes the substantive empirical results. Finally, Section 4 concludes.

\section{Data and empirical framework}

\subsection{Data description}

To examine the relation between German firms' derivatives use and the cost of equity capital, we use hand-collected data. In particular, we first obtain the annual reports of publicly listed German non-financial firms available in English from their respective official websites. ${ }^{1}$ Our sample period spans 1999 to 2009. We then use the following keywords to search for information on derivatives use and hedging strategies in each of the annual reports: "hedge", "derivative", "market risk", "exposure", "foreign", "currency", "interest rate", "commodity", "futures", "option", "swap", "risk management", "forward", and "financial instrument". When we find a keyword, we read the surrounding text to identify if the firm is a derivatives user or

\footnotetext{
${ }^{1}$ We exclude financial firms from our empirical analysis since risk management incentives for financial and non-financial firms are not necessarily comparable. For example, proprietary trading activities by financial firms might motivate them to take on speculative derivative positions. Hence, inclusion of financial firms in our analysis could potentially lead to spurious results.
} 
not for a given year. If the text surrounding a keyword provides any information on derivatives use or suggests that the respective firm is using derivative instrument(s) then we consider that firm-year as a user of derivatives and hand-code it to "1" for the "derivatives use" dummy variable. We classify a firm-year observation as a derivatives non-user if there is no information on derivatives use available in the annual report and hand-code it to "0" for the "derivatives use" dummy variable. Likewise, we also construct dummy variables for each specific category of the derivative instruments, namely, foreign currency, interest rate, and commodity derivatives. ${ }^{2}$

Our sample consists of 357 firms with 1984 firm-year observations of which 1388 firm-year observations show use of derivatives and 596 firm-year observations show non-use. These numbers indicate that about $70 \%$ of our firm-year observations use derivative instruments. This is notably a higher percentage of derivatives use compared to many recent studies (see, among others, Adam, Dasgupta, and Titman, 2007; Campello, Lin, Ma, and Zou, 2011; Gay, Lin, and Smith, 2011). Bodnar and Gebhardt (1999) also find from a survey that $78 \%$ of German firms use derivative instruments. Moreover, our sample composition differs from those of prior empirical studies, which predominantly consider large firms (see, for example, Adam and Fernando, 2006; Gay, Lin, and Smith, 2011). In other words, our sample contains both small and large German non-financial firms. This allows us to avoid possible biased results due to the selection of large firms only in the empirical analysis.

We retrieve firm-level financial and accounting information from Thomson Reuters via Datastream. Later, to investigate the relation between derivatives use and financial distress risk, we source 1- and 5-year EDF values, computed using the KMV-Merton framework due to Merton (1974), from Moody's Analytics. Following standard practice in the literature (see, for example, Fama and French, 2006), all of our continuous explanatory variables are winsorized at the top and bottom $1 \%$ of each variable's distribution in order to mitigate the undue influence of outliers on the empirical results. We present descriptive statistics and a correlation matrix of the firm-level characteristic variables in Tables A.1 and A.2 of the Appendix, respectively.

\subsection{Estimating a firm's cost of equity}

Consistent with the literature (see, among others, D'Mello and Shroff, 2000; Gay, Lin, and Smith, 2011, and references therein), we use the Fama and French (1993) three-factor model to

\footnotetext{
${ }^{2}$ The reasons to use dummy variables instead of scaled total notional amounts or net derivatives positions are that the German domestic Generally Accepted Accounting Principle (GAAP) prior to 2010 did not have any specific hedge accounting disclosure requirement. In addition, many German firms adopted the International Financial Reporting Standards (IFRS) after 2009. However, hedge accounting is optional for firms following IFRS9. Furthermore, neither German GAAP nor IFRS9 requires firms to quantify the notional amount of derivatives holdings.
} 
compute the equity premium for each non-financial German firm. ${ }^{3}$ More precisely, we first run the following time-series regression using daily returns for firm $i$ in a given year:

$$
R_{i, t}-R_{f, t}=a_{i}+\sum_{k=-1}^{k=1} b_{i, k}\left(R_{M, t+k}-R_{f, t+k}\right)+\sum_{k=-1}^{k=1} s_{i, k} S M B_{t+k}+\sum_{k=-1}^{k=1} h_{i, k} H M L_{t+k}+e_{i, t}
$$

where $R_{i, t}$ is the return for firm $i$ in period $t ;{ }^{4} R_{f, t}$ is the return on the risk-free security in period $t ;^{5}$ and $R_{M, t}, S M B_{t}$, and $H M L_{t}$ are the returns of the market, size, and value factor mimicking portfolios, respectively, in time period $t .{ }^{6}$ The beta coefficients (i.e., $b_{i}, s_{i}$, and $h_{i}$ ) represent the factor sensitivities or loadings and $e_{i, t}$ represents the (zero-mean) regression residual. In the time-series regression specification given by equation (1), the rationale for including one lead and lag return in addition to the contemporaneous daily return is to account for infrequent trading (see Dimson, 1979). ${ }^{7}$ Accordingly, we obtain each market, SMB, and HML beta as the sum of the coefficient estimates on the lag, contemporaneous, and lead values of the corresponding factor risk premiums.

Following Fama and French (1997) and D'Mello and Shroff (2000), we then compute the cost of equity for each firm-year as an annual risk premium given by

$$
C E_{i, t}=E\left(R_{i, t}\right)-R_{f}=\hat{B}_{i, t}\left[E\left(R_{M}\right)-R_{f}\right]+\hat{S}_{i, t} E(S M B)+\hat{H}_{i, t} E(H M L)
$$

where $C E_{i, t}$ is the cost of equity of firm $i$, and $\hat{B}_{i, t}, \hat{S}_{i, t}$, and $\hat{H}_{i, t}$ are the estimated betas for the market, SMB, and HML risk factors, respectively, in period $t$. For a given year, the expectations of the $R_{M}-R_{f}$, SMB, and HML are the arithmetic average of daily returns of each factor for the corresponding year. The cost of equity estimates are then annualized by multiplying by 252 . We also compute the industry-adjusted cost of equity of a firm as the difference between its estimated cost of equity and the median industry cost of equity estimate for a given year.

\subsection{Construction of factors}

To construct the market, size, and value risk factor mimicking portfolios (i.e., $R_{M}$, SMB, and HML), we first collect daily total return indexes (adjusted for stock splits and dividend

\footnotetext{
${ }^{3}$ In the context of German firms, Schrimpf, Schröder, and Stehle (2007) find that the Fama and French (1993) three-factor model performs well in explaining the cross-section of stock returns.

${ }^{4}$ In our case, daily returns for a given firm are computed using its daily total return index, which is adjusted for firm's stock splits and dividend payments. To help establish the robustness of our findings, we also conduct empirical analysis where weekly returns are used to compute the cost of equity of a firm. The results from this exercise are similar to the baseline findings of the paper and are reported in Tables A.3 and A.4 of the Appendix.

${ }^{5}$ We use one-month money market rate for Germany as a proxy for the return on the risk-free security.

${ }^{6}$ Details on the construction of the market, size, and value factors for Germany are provided in Section 2.3.

7 In an unreported analysis, we find that our empirical results are not sensitive to alternative specifications including no lags or leads.
} 
payments) of all listed common stocks in Germany irrespective of the Exchanges for the period between January 1998 to December 2009 from Datastream. ${ }^{8,9}$ Thereafter, we calculate market capitalization and book-to-market ratio of a firm's common stock by following the methods suggested in Fama and French (1993). Market capitalization is therefore computed as the number of equity shares outstanding times the price of one share at the end of June in each year $t$. In June of year $t+1$, we recalculate market capitalization. The book-to-market ratio is calculated in June of each year $t$ as the ratio of the book value of a firm's common equity at the end of the fiscal year ending in the calendar year $t-1$ to the market capitalization of the stock at the end of December in calendar year $t-1$. Similar to market capitalization, we also recalculate book-to-market ratio in June of year $t+1$.

We compute the daily return for the market risk factor mimicking portfolio as the valueweighted portfolio return of all aforementioned common stocks. The market capitalization defined above is used as the weight variable. To construct the size and value risk factor mimicking portfolios, SMB and HML, in any day as per Fama and French (1993), we begin by sorting all common stocks into two groups. On the last trading day of June in each year $t$, stocks with market capitalizations that are lower than the median market capitalization among all available stocks are assigned to the Small group, while stocks with market capitalizations that are above the median market capitalization are assigned to the Big group. At the end of June in each year $t$, the entire universe of German common stocks is also independently sorted into three groups based on the book-to-market ratio defined above. The High group holds stocks with book-to-market ratios above the 70th percentile of book-to-market ratios for all available stocks. The Medium group contains stocks with book-to-market ratios between the 30th and 70th percentiles. The Low group comprises stocks with book-to-market ratios below the 30th percentile. We then intersect the two market capitalization-based groups and three book-to-market-based groups to create six portfolios. These portfolios are denoted as Small High, Small Medium, Small Low, Big High, Big Medium, and Big Low. The Small High portfolio holds stocks in the intersection of the Small market capitalization group and the High book-to-market ratio group. Stock compositions of the other five portfolios are analogous. We calculate the daily

\footnotetext{
${ }^{8}$ For Germany, the default search option for "total return index" in Datastream only retrieves the stocks listed in the Frankfurt Stock Exchange (FSE). To obtain return information for a stock that is not listed in the FSE, we first identify the Exchange in which the firm is listed and then use the Exchange code to collect the total return index data for that firm's stock. If the firm is cross-listed in the FSE and other Exchanges then we consider the FSE data only.

${ }^{9}$ The Fama and French (1993) three factors for Germany are publicly available in the Humboldt University of Berlin website (https://www.wiwi.hu-berlin.de/de/professuren/bwl/bb/data/fama-french-factors-germany/ fama-french-factors-for-germany). However, these factors are constructed using both common and preferred stocks, and abandon bottom $20 \%$ market capitalization firms. This could potentially undermine the size effect. To overcome this issue, we construct the factors using all publicly listed common stocks. In an unreported exercise, we find that our empirical results hold even with the three factors available in the aforementioned source.
} 
return of each of the six portfolios. The stocks within each portfolio are value-weighted, with the market capitalization at the end of June of year $t$, used as the weight variable. ${ }^{10}$

The return of the size factor mimicking portfolio in any trading day is then obtained as $S M B=1 / 3($ Small High + Small Medium + Small Low $)-1 / 3($ Big High + Big Medium + Big Low). On the other hand, the daily return of the value factor mimicking portfolio is computed as $H M L=1 / 2($ Small High + Big High $)-1 / 2($ Small Low + Big Low $)$. By construction, the HML portfolio isolates the relation between book-to-market ratio and stock returns while controlling for the market capitalization effect.

\subsection{Multivariate framework}

We resort to a multivariate regression framework in which the relation between firms' cost of equity capital and their use of derivatives is specified as

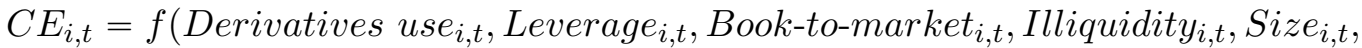

$$
\begin{aligned}
& \text { Number of segments } \left.s_{i, t}, \% \text { Segment sales }{ }_{i, s, t}, \text { Ownership } 30_{i, t}, \text { Ownership } 30_{i, t}^{+}\right) \text {. }
\end{aligned}
$$

Derivatives use is a dummy variable defined earlier in Section 2.1. Our rationale for using leverage is to proxy for default risk (see Campello, Lin, Ma, and Zou, 2011; Lin, Ma, Malatesta, and Xuan, 2011; Purnanandam, 2008, and references therein). Leverage is defined as long-term debt plus current portion of long-term debt scaled by total assets. We expect a positive link between the cost of equity and the level of leverage. Importantly, leverage of a firm depends on industry-specific characteristics (see Lang, Ofek, and Stulz, 1996). Considering this fact, we also calculate the industry-adjusted leverage of a firm. For a given year, this is computed as the difference between a firm's leverage estimate defined above and the median industry leverage estimate. In this case, we repeat our empirical analysis using the industry-adjusted cost of equity, defined in Section 2.2, for consistency. The book-to-market ratio, defined previously, is included to proxy for a firm's growth opportunities (see, among others, Bartram, Brown, and Conrad, 2011; Gay, Lin, and Smith, 2011). Illiquidity is the Amihud (2002) liquidity measure, computed as the ratio of the absolute value of the daily stock return to the daily euro trading volume of the stock, averaged over all trading days (with non-zero volume) available in a given year. We expect a positive relation between the cost of equity and illiquidity. Size is defined as the natural logarithm of total assets. Firm size is expected to be negatively related to

\footnotetext{
10 Although we update the weights as of the end of June in each year $t$, the return data for all common stocks are updated on a trading day basis to compute the daily returns of the market, size, and value risk factor mimicking portfolios used in the empirical analysis.
} 
the cost of equity since small firms tend to have higher risk than large firms. We consider the number of business segments in which a firm operates to proxy for firm's operational risk diversification (see Chod, Rudi, and Mieghem, 2010). Diversified firms are exposed to lower levels of risk than non-diversified firms. We, therefore, expect a negative relation between the cost of equity capital and the number of segments. We also incorporate the percentage of a firm's sales in each industry segment $s$ to control for potential industry effects. Unlike the US, blockholder ownership is a common phenomenon in Germany (see, among others, Franks and Mayer, 2001; Gorton and Schmid, 2000). ${ }^{11}$ Hence, we control for blockholder ownership by incorporating two ownership dummy variables, namely, ownership30 and ownership $30^{+}$. In particular, ownership30 takes the value 1 if a firm's blockholder ownership is between $10 \%$ and $30 \%$ and zero otherwise. Likewise, ownership $30^{+}$takes the value 1 if a firm's blockholder ownership is above $30 \%$ and zero otherwise.

We conduct our baseline multivariate analysis using the pooled ordinary least squares (OLS) regression method. However, our statistical inferences can be criticized due to potential endogeneity resulting from a firm's financial hedging and capital structure decisions. In other words, the pooled OLS estimation of the relation specified by equation (3) assumes that the decision by a firm to use derivative instruments is exogenous. But in reality, it is more likely to be an endogenous decision (Gay, Lin, and Smith, 2011). This follows from the well-known debt capacity argument, put forth in Leland (1998) and Stulz (1986), that hedging increases a firm's debt capacity and therefore reduces tax liabilities due to increases in the level of leverage. In support of this line of reasoning, Graham and Rogers (2002) provide evidence that firms with higher leverage are more likely to hedge for risk management purpose and that hedging also leads to a higher level of leverage. Hence, to address the above potential endogeneity problem, we also examine the cost of equity capital, derivatives use, and leverage decisions of our sample of non-financial German firms within a simultaneous equations framework. This enables us to avoid spurious statistical inferences of causality among these crucial decisions.

In line with Gay, Lin, and Smith (2011) and Géczy, Minton, and Schrand (1997), we consider

\footnotetext{
11 The relation between the cost of equity and blockholder ownership is ambiguous in the literature due to mixed evidence. For example, Ashbaugh, Collins, and LaFond (2004) suggest a positive relation between the concentrated ownership and the cost of equity due to the extraction of private benefits of control by the blockholders. In contrast, Attig, Guedhami, and Mishra (2008) show that blockholder ownership reduces the cost of equity capital by reducing a firm's agency and information related problems.
} 
the following specification to model the derivatives use decision:

$$
\begin{gathered}
{\text { Derivatives } \text { use }_{i, t}=f}\left(\text { Leverage }_{i, t}, \text { Book-to-market }_{i, t}, \text { Size }_{i, t}, \text { Number of segments }_{i, t},\right. \\
\\
\% \text { Segment sales }_{i, s, t}, \text { Quick ratio }_{i, t}, \text { Foreign sales to net sales }_{i, t}, \\
\text { Ownership } \left.30_{i, t}, \text { Ownership } 30_{i, t}^{+}, \text {Year dummies }\right) .
\end{gathered}
$$

A strand of literature (see, among others, Bessembinder, 1991; Froot, Scharfstein, and Stein, 1993; Rampini and Viswanathan, 2010) suggests that the use of derivative instruments can help reduce the underinvestment problem of a firm. The book-to-market ratio is incorporated on the grounds that firms with lower book-to-market ratios (i.e., higher growth opportunities) are more likely to engage in hedging activities. Hence, we expect a negative link between derivatives use and the book-to-market ratio. Size is included in our analysis to proxy for economies of scale in the costs of risk management. ${ }^{12}$ We make use of a firm's number of business segments in which it operates as well as the quick ratio to proxy as substitutes for derivative instruments use. Firms operating in different business segments are likely to have lower risk due to product diversification (Gay, Lin, and Smith, 2011). We, therefore, expect a negative association between derivatives use and the number of business segments. The quick ratio, defined as the ratio of cash and short-term investments to current liabilities, is also expected to be negatively related to derivatives use. We utilize the ratio of foreign sales to net sales in order to account for the foreign currency risk exposure of a firm, which is expected to be positively related to derivatives use (see Allayannis and Weston, 2001; Lin, Phillips, and Smith, 2008). Once again, we include ownership30 and ownership30 ${ }^{+}$dummy variables in order to control for blockholder ownership. Furthermore, the percentage of segment sales and year dummies are incorporated to control for industry and time effects, respectively. ${ }^{13}$

We follow studies by Gay, Lin, and Smith (2011), Géczy, Minton, and Schrand (1997), and Titman and Wessels (1988) for the leverage specification. This is given by

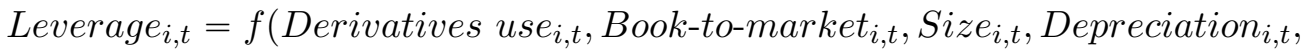

$$
\begin{aligned}
& \text { Property, plant, and equipment }{ }_{i, t}, \text { Return on asset } s_{i, t}, S G A \text { expenses } s_{i, t}, \\
& \% \text { Segment sales }_{i, s, t}, \text { Ownership } 30_{i, t}, \text { Ownership } 30_{i, t}^{+}, \text {Year dummies). }
\end{aligned}
$$

\footnotetext{
${ }^{12}$ The relation between derivatives use and firm size is inconclusive in the literature. On the one hand, Warner (1977) shows that the direct costs related to financial distress are less than proportional to firm size. This suggests that small firms are more likely to participate in hedging activities. On the other hand, Block and Gallagher (1986) argue that hedging exhibits informational scale economies and that larger firms are more likely to hedge.

${ }^{13}$ We also consider an alternative specification of equation (4), where industry dummies replace segment sales percentages. The results from this unreported analysis are qualitatively similar to those provided in this paper.
} 
Leland (1998) argues that firms using derivatives can increase their debt capacity by reducing financial distress. Recent empirical evidence provided by Purnanandam (2008) supports this argument. We, therefore, expect a positive relation between the level of leverage and derivatives use. Myers (1977) argues that firms with investment opportunities that could make a positive net contribution to their market values are more likely to have a lower level of debt. Consistent with this argument, we expect a positive association between the book-to-market ratio and leverage. Financial constraints of a firm are proxied by its size (see Adam, 2009). Thus, we expect firm size to exhibit a positive relation to the level of leverage. Tax related motive is proxied by the ratio of depreciation expenses to total assets. Depreciation acts as a nondebt tax shield for firms (DeAngelo and Masulis, 1980). Hence, firms with higher depreciation expenses will have less incentive to increase their leverage levels. Leverage is dependent on a firm's profitability. We include return on assets as a proxy for a firm's profitability. Return on assets is computed as the ratio of earnings before extraordinary items to total assets. We expect return on assets to be negatively related to leverage (see Gay, Lin, and Smith, 2011). Further, we compute the ratio of selling, general, and administrative expenses to total assets (referred to as SGA expenses) as a proxy for the uniqueness of the firm's products. Firms with relatively unique line of products are exposed to higher bankruptcy costs (Titman and Wessels, 1988). Hence, a negative relationship between the level of leverage and the degree of a firm's uniqueness is expected. We consider property, plant, and equipment scaled by total assets as a proxy for collateral value. Firms with higher collateral value can have higher leverage and therefore a positive association between leverage and property, plant, and equipment is expected. Similar to the model of derivatives use decision given by equation (4), we also control for blockholder ownership, industry, and time effects. In other words, we include the percentage segment sales, ownership30, ownership30 ${ }^{+}$, and year dummy variables in our analysis.

\section{Empirical results}

\subsection{Univariate results}

Table 2 presents mean and median values of the cost of equity, industry-adjusted cost of equity, and market (i.e., $R_{M}-R_{f}$ ), SMB, and HML factor betas separately for all firm, derivatives user, and non-user groups. ${ }^{14}$ We also report differences in mean and median values between users and non-users in relation to the aforementioned variables. Our univariate comparison provides strong evidence that derivatives user German non-financial firms have, on average, a

\footnotetext{
${ }^{14}$ We elaborate on the mean and median values of 1- and 5-year EDF in Section 3.6.
} 
lower cost of equity over the sample period. A similar empirical finding emerges when we focus on the industry-adjusted cost of equity estimates. Specifically, derivatives users markedly have a 306 (299) basis point lower cost of equity than do non-users based on mean (median) values. Looking at the industry-adjusted estimates, we find that user firms have a 109 (118) basis point lower cost of equity than do non-users based on mean (median) values. All of these mean and median difference estimates are economically large and statistically significant at the $1 \%$ level. Further, the mean and median differences in risk factor betas affirm that derivatives user firms have significantly lower market, SMB, and HML betas than non-users. Considering the market beta, we observe that derivatives users have an average of 0.8128 versus 1.1169 for non-users. For the SMB beta, user firms have an average of 0.5023 as compared to the non-user average of 0.8718. Similarly, for the HML beta, derivatives users have an average of 0.3289 versus 0.3922 for non-users. These perceived differences suggest that user firms experience their largest reductions in risk factor betas over non-users from the SMB beta, which is 0.3695 (or $42.38 \%$ ) on average. This is followed by reductions in the market and HML factor betas by 0.3040 (or $27.22 \%$ ) and 0.0633 (or $16.14 \%$ ), respectively. ${ }^{15}$

We now elaborate on the relative effect of the differences in the mean values of the factor betas on the overall difference in the average cost of equity capital between user and non-user groups. To do so, we first compute the average annual risk premiums over our sample period for the market, SMB, and HML risk factors. The average annual risk premiums of these factors are $0.0497,0.0312$, and 0.0620 respectively. We then multiply the risk premium estimate for each factor by the difference in the mean values of the corresponding factor betas between users and non-users. This provides us the approximate contribution of each beta component to the overall difference in the cost of equity. We find that the market beta component contributes to the reduction in the cost of equity by 151 basis points $(-0.3040 \times 0.0497)$ for derivatives user firms. The contribution of the SMB beta component to the reduction in the cost of equity is 115 basis points $(-0.3695 \times 0.0312)$ for derivatives users, whereas the contribution of the HML beta component is 39 basis points $(-0.0633 \times 0.0620)$. These results suggest that the lower cost of equity for derivatives user firms is driven by their lower exposures to the market, SMB, and HML risk factors. Our empirical finding on the contributions of the SMB and HML betas to the significant reduction in the cost of equity of derivatives users is also consistent with the notion that hedging through the use of derivatives is associated with the alleviation of financial distress risk, which in turns leads to lower SMB and HML betas.

\footnotetext{
${ }^{15}$ We acknowledge that beta estimates from individual firm regressions can be noisy and therefore it is possible that derivatives usage could be associated with lower measured backward-looking sensitivities to the Fama-French factors for Germany rather than expectations of lower sensitivities in the future. We thank an anonymous referee for pointing this out.
} 


\subsection{Multivariate results}

\subsubsection{Pooled OLS regression results}

We present the results of the estimated relation between firms' industry-adjusted cost of equity and their use of derivatives in Table $3 .{ }^{16,17}$ The specification of our first model (referred to as model 1) excludes blockholder ownership dummy variables, whereas the specification of the second model (referred to as model 2) includes them. Starting with model 1, we observe that the derivatives use dummy is significantly negative at the $1 \%$ level. The estimated coefficient of -0.0160 indicates that derivatives user firms have a 160 basis point lower cost of equity than non-users. Said differently, firms that use derivative instruments indeed experience a sizeable reduction in the cost of equity. It is worth mentioning that Gay, Lin, and Smith (2011) provide qualitatively similar empirical evidence based on a large sample of US non-financial firms. We also notice that the estimated coefficients on the control variables have their expected signs as discussed in Section 2.4. With the exception of the number of segments, all of them are statistically significant even at the $1 \%$ level. Similar empirical findings emerge when focusing on model 2, which also controls for blockholder ownership. Importantly, the estimated coefficient of -0.0139 on the derivatives use dummy variable is statistically significant at the $1 \%$ level. Consistent with Attig, Guedhami, and Mishra (2008), we find a negative relation between the cost of equity capital and large blockholder ownership. The estimated coefficient of -0.0183 on the ownership $30^{+}$dummy is statistically significant at the $1 \%$ level. We note that these baseline empirical findings also hold when we repeat the entire analysis using lagged firm-level control variables. To conserve space, these results are not reported in this paper. Furthermore, we only present results based on model 2 in subsequent sections.

\subsubsection{Simultaneous equations results}

As pointed out earlier, our empirical findings based on the pooled OLS regressions can be criticized due to the possibility of a firm's financial hedging decision being endogenous. In this section, we address this concern by estimating the industry-adjusted cost of equity, derivatives use, and industry-adjusted leverage equations within a simultaneous equations framework. ${ }^{18}$ We utilize a two-stage estimation procedure to obtain the parameter estimates. The first stage

\footnotetext{
16 The results based on the unadjusted cost of equity are qualitatively similar to those reported in this section; these are available upon request.

${ }^{17}$ All standard errors of coefficient estimates are adjusted for simultaneous clustering on firm and year to avoid inflated $t$-statistics.

${ }^{18}$ To conserve space, the results from the simultaneous equations analysis based on the unadjusted cost of equity, derivatives use, and unadjusted leverage are omitted in this paper. These results, qualitatively similar to those reported in this section, are available upon request.
} 
proceeds by separately running an OLS regression for the industry-adjusted leverage and a probit regression for the derivatives use decision. The second stage involves estimating a structural equation where the relevant explanatory variables are replaced with the corresponding predicted values obtained from the first-stage regressions. ${ }^{19}$ The results reported in Table 4 suggest that our preceding baseline empirical findings hold even after accounting for potential endogeneity. Importantly, we observe a negative relation between the cost of equity capital and a firm's derivatives use. The estimated coefficient of -0.0236 on the derivatives use dummy variable is statistically significant at the $1 \%$ level. We emphasize that this is higher than the corresponding coefficient of -0.0203 in Gay, Lin, and Smith (2011). Moreover, the magnitude of the coefficient estimate is consistent with our a priori expectations that the impact of derivatives use on the cost of equity capital in a German setting is likely to be higher than a US setting because of key institutional differences as shown in Table 1. Specifically, in a German institutional setting where shareholder rights are lower and creditor rights are higher, there is generally a greater likelihood of a firm entering liquidation proceedings, greater costs of bankruptcy and therefore higher expected costs of financial distress. For example, the German bankruptcy code provides creditors with the ability to liquidate after the compulsory stay of three months has been exhausted, whereas in Chapter 11 there are strong automatic stay provisions. All of these would imply a greater incentive to hedge for German firms because of a larger potential reduction in the costs of financial distress. In view of this, our finding of a larger impact of derivatives use on the cost of equity capital in a German setting compared to that in the US is not surprising.

Furthermore, the relatively large impact of derivatives on the cost of equity could be due to one or more of the following reasons. First, as pointed out by Guay and Kothari (2003), firms might also be conducting operational hedging activities at the same time as their financial derivatives hedging. In such case, our estimate might be capturing both effects generating a relatively large reduction in the cost of equity capital. Second, the period of our study includes the bursting of the "dot-com bubble" around the time of the millennium, a string of audit scandals, rising commodity prices, and the 2007-2009 global financial crisis resulting in a prolonged period of heightened economic uncertainty. In this environment, financial risk mitigation through derivatives could have had a larger impact. Lastly, the volatility of the nominal effective exchange rate for the euro during the period of our study is $13 \%$ higher than the period from 2010 to 2017, suggesting a period of elevated exchange rate volatility. This might also go some way in explaining our empirical results.

When looking at the derivatives use model specified by equation (4), we find that the

\footnotetext{
${ }^{19}$ We also incorporate year dummies to control for time effects while estimating the cost of equity equation within the simultaneous equations system.
} 
industry-adjusted leverage, firm size, and foreign sales to net sales variables, and the ownership30 ${ }^{+}$ dummy variable are positively related to the derivatives use decision. As expected, the quick ratio is negatively related to a firm's derivatives use. The estimated coefficients on these variables are also statistically significant at the $1 \%$ or $5 \%$ level. Consistent with Géczy, Minton, and Schrand (1997) and Gay, Lin, and Smith (2011), we do not find a significant relation between the derivatives hedging decision and the book-to-market ratio. A similar conclusion emerges both for the number of segments variable and the ownership30 dummy variable.

For the leverage specification, we see a significantly positive relation between the industryadjusted leverage and derivatives use. This empirical finding is consistent with the well-known debt capacity argument raised in Leland (1998). Firm size and property, plant, and equipment are positively correlated with the industry-adjusted leverage. As expected, return on assets and depreciation are negatively correlated with the level of leverage. However, we do not find a significant relation between the industry-adjusted leverage and SGA expenses. A statistically insignificant relation with the industry-adjusted leverage also appears for our blockholder ownership dummy variables. Finally, we cannot reject the joint null hypothesis that the instruments are valid and the excluded instruments are correctly excluded from the estimated equation: the $p$-value of the Sargan-Hansen statistic exceeds $10 \%$.

\subsubsection{Propensity score matching results}

In Table A.1 of the Appendix, it can be seen that there are significant differences in the characteristics of derivatives user and non-user firms. As a result, our earlier finding that derivatives use reduces the cost of equity capital may suffer from a sample selection bias. We now investigate this issue by conducting a matching analysis. In particular, we first obtain the predicted probabilities (propensity scores) of derivatives use computed from a probit regression model given by equation (4). We then match (without replacement) user firms with non-users on the basis of their (estimated) propensity to use financial derivatives. Table 5 presents mean and median values of the variables that we examine in Table 2 for derivatives users and nonusers, but matched on their propensity scores. Looking at the mean (median) values, we notice that firms that use derivatives have a significant 111 (115) basis point lower cost of equity than matched firms that do not. We also find that user firms have a significant 75 (83) basis point lower industry-adjusted cost of equity than non-user matched firms based on mean (median) values. Furthermore, derivatives user firms have significantly lower market, SMB, and HML factor betas than non-users. All these empirical results, consistent with those reported in Tables 2 through 4, mitigate concerns of a potential sample selection bias. 


\subsection{Effects of firm size}

To further deepen our understanding of the preceding empirical findings, we now investigate the effect of firm size on the relation between derivatives use and the cost of equity capital. In each year, we assign our sample of German non-financial firms to size terciles. By construction, tercile 1 (tercile 3) comprises the smallest (largest) one-third of the sample firms. We present the results of the univariate analysis in Table 6. In Panel A for the sample of smaller firms (tercile 1), we see that derivatives users have a 237 (211) basis point lower cost of equity than non-users based on difference in mean (median) values, an estimate statistically significant at the $1 \%$ level. For the industry-adjusted estimates, users have a 94 (104) basis point lower cost of equity than non-users based on mean (median) values. We also observe that user firms have significantly lower risk factor betas than non-users. For example, the average market, SMB, and HML betas for the user group are 1.0523, 0.5423, and 0.3172 , respectively. The corresponding estimates for the non-user group are, respectively, 1.1959, 0.9144, and 0.3968.

In Panel B for mid-size firms (tercile 2), we find that derivatives users have a 141 (149) basis point lower cost of equity than non-users based on mean (median) values. Also, firms that use derivatives have a 61 (60) basis point lower industry-adjusted cost of equity than non-users based on mean (median) values. These differences in mean (median) values between user and non-user groups are statistically significant at the $1 \%$ or $5 \%$ level. More so, derivatives user firms have lower market, SMB, and HML factor betas than non-users. But the mean and median differences in HML beta are statistically insignificant at conventional levels. For the sample of larger firms (tercile 3) in Panel C, the estimated cost of equity of user firms is significantly lower than that of non-users by 96 (89) basis points based on mean (median) values. Moreover, derivatives user firms have a significantly lower HML beta than do non-users.

The empirical results in Table 6 also offer evidence that both the unadjusted and industryadjusted cost of equity estimates are decreasing in firm size. This is consistent with our earlier results, reported in Tables 3 and 4, which show that a firm's cost of equity capital is negatively correlated with its size. Furthermore, Table 6 demonstrates that the mean and median values for the market, SMB, and HML factor betas are decreasing in firm size.

Using a multivariate framework, we now examine the relation between firms' industryadjusted cost of equity and their use of derivatives broken down into size terciles. Table 7 presents the results from the pooled OLS regressions. We observe, for the sample of smaller firms (tercile 1 ), that the estimated coefficient of -0.0215 on the derivatives use dummy variable is statistically significant at the $1 \%$ level. This coefficient estimate suggests that user firms in 
the smaller tercile have a lower cost of equity than non-users. ${ }^{20}$ Similar to that in Gay, Lin, and Smith (2011), we do not find a significantly negative association between the cost of equity capital and derivative instruments use for the samples of mid-size (tercile 2) and larger (tercile 3) firms. This finding is consistent with the fact that as larger firms tend to be more diversified in both a product and geographical sense, they possess lower residual financial price exposure. Consequently, they are likely to use financial derivatives less intensely than smaller firms, such as hedging selectively, resulting in a lesser impact on the cost of equity capital.

\subsection{Type of derivatives use}

In the context of the relation between German firm's hedging activities, through the derivatives use, and the cost of equity, it is also interesting to know whether the type of derivatives matters. To shed light on this issue, we repeat our baseline pooled OLS regression analysis by instead including three separate dummy variables for foreign currency, interest rate, and commodity derivatives use. Table 8 presents the results based on the industry-adjusted cost of equity. We see that the estimated coefficients of -0.0094 and -0.0032 , respectively, on the foreign currency and interest rate derivatives use dummies are statistically significant. This in turn implies that the use of both derivatives contributes to the overall reduction in firms' cost of equity. More so, the estimated coefficient on the foreign currency derivatives use is significantly higher in absolute terms than that of the interest rate derivatives use coefficient. The $p$-value for the test of the null hypothesis that the coefficients are equal is 0.0487. This finding is not surprising considering the fact that listed German firms export a significant share of their output outside of the European Union, which exposes them to higher levels of exchange rate risk as compared to their exposure to interest rate movements. However, our estimated coefficient of -0.0016 on the commodity derivatives use dummy variable is statistically indistinguishable from zero at conventional levels. ${ }^{21}$ In sum, the empirical evidence suggests that the use of foreign currency and, to a lesser extent, interest rate derivatives helps reduce the cost of equity estimates for derivatives user German non-financial firms in our sample. We note that Gay, Lin, and Smith (2011) also report a similar finding in the context of US non-financial firms.

\subsection{New users of derivatives}

In our preceding empirical analysis, one could argue that derivatives non-user group is not an appropriate benchmark for comparing users due to differences in firm-level characteristics.

\footnotetext{
${ }^{20}$ We find qualitatively similar results in an unreported exercise based on the unadjusted cost of equity.

21 The results based on the unadjusted cost of equity are qualitatively similar to those reported in this section. To conserve space, these are omitted in this paper.
} 
To help mitigate this concern, we also investigate the change in the cost of equity capital experienced by firms that were non-users of derivatives and subsequently initiated derivatives programs. Following Gay, Lin, and Smith (2011), a firm is categorized as a new user of derivative instrument(s) if it reports derivatives use in year $t$, but does not report a position in derivatives prior to year $t$ during our sample period. This classification gives us a sub-sample of 86 nonfinancial firms that are identified as new users of derivatives.

Table 9 presents mean and median changes in the cost of equity, industry-adjusted cost of equity, and market, SMB, and HML factor betas. Consistent with our baseline empirical results, we find that new users experience a significant mean (median) reduction in the cost of equity of 246 (253) basis points in the first year of adoption. The mean and median reductions in the industry-adjusted cost of equity are, respectively, 286 and 287 basis points. Both of these estimates are statistically significant at the $1 \%$ level. New user firms also experience a significant mean (median) reduction in their market, SMB, and HML factor betas. ${ }^{22}$

\subsection{Derivatives use and financial distress risk}

In Section 3.1, we find that the cost of equity of derivatives users is significantly lower than that of non-users. This reduction is attributable to user firms having significantly lower market, SMB, and HML factor betas. Fama and French (1996) argue that the slopes on SMB and HML factors proxy for relative financial distress. Consistent with this argument, Vassalou and Xing (2004) provide empirical evidence that the Fama and French (1993) factors SMB and HML contain information regarding default risk. Thus, our empirical finding is consistent with the idea that the use of derivative instruments by firms is linked with the alleviation of their financial distress risk, which in turn leads to lower SMB and HML factor betas. Campbell, Hilscher, and Szilagyi (2008), however, show that although firms with higher financial distress risk have higher SMB and HML betas, they can also have lower average stock returns than do firms with relatively low financial distress. Hence, the distress risk representation of the Fama and French (1993) three-factor model is incongruent. In this regard, our reasoning, based on the empirical finding in Section 3.1, that derivatives hedging reduces financial distress risk which in turn lowers cost of equity can be criticized due to proxy selection. We address this concern, in this section, by using both 1- and 5- year EDF values as a proxy for financial distress risk of firms to investigate the impact of hedging activities on the probability of default. ${ }^{23}$ More

\footnotetext{
${ }^{22}$ We acknowledge that there is a possibility that our empirical analysis of new derivatives users is affected by endogeneity. Ideally, we would like to conduct an analysis of new users in a multivariate setting. But due to the lack of publicly available data on the notional amount of derivatives use, we are unable to employ an effective measure of the change in the extent of financial derivatives use.

${ }^{23}$ The 1-year (5-year) EDF value is defined as the probability that a firm will default in 1-year (5-year) time.
} 
precisely, we resort to the following model specification:

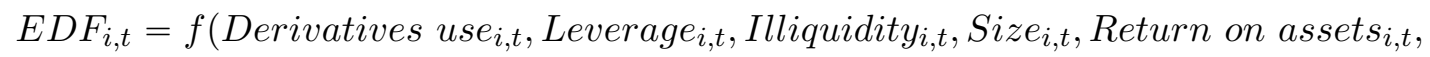

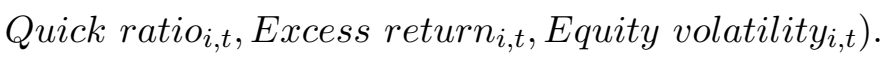

Along the lines of Froot, Scharfstein, and Stein (1993) and Smith and Stulz (1985), we expect that derivatives user firms have a lower EDF than non-users. Firms with a higher level of leverage are exposed to a higher level of financial distress risk. Thus, we expect a positive association between EDF and leverage. Disproportional effect of firm size on financial distress as argued by Warner (1977) suggests that size is negatively related to EDF. Firms with higher return on assets are more likely to have lower EDF and therefore a negative relation between them is expected. Recently, Brogaard, Li, and Xia (2017) show that the higher stock-level liquidity reduces financial distress risk. We expect a positive association between EDF and illiquidity. In relation to the quick ratio, Haushalter, Klasa, and Maxwell (2007) find that firms with a lower quick ratio are more likely to have a higher probability of default. Following Bharath and Shumway (2008) and Brogaard, Li, and Xia (2017), we also consider excess return, which is computed as the difference between a stock's annual return and annual return on our value-weighted market portfolio constructed in Section 2.3. Finally, equity volatility is obtained as the standard deviation over one year of daily returns and then annualized by multiplying by $\sqrt{252}$. We expect equity volatility to exhibit a positive association with EDF.

Before moving to the multivariate analysis, we briefly discuss the univariate results of the differences in mean and median values of both 1-year and 5-year EDF between the derivatives user and non-user groups. From Table 2, it is observable that the mean (median) values of 1-year and 5-year EDF for user firms are lower than non-users, respectively, by 1.16 (1.82) percentage points and 1.11 (1.89) percentage points. Importantly, these estimates are statistically significant even at the $1 \%$ level. We report the univariate results for derivatives user and non-user firms broken down into size terciles in Table 6. In all size terciles, firms that use derivative instruments have significantly lower 1-year and 5-year EDF compared to non-users based on mean (median) values. Moreover, both mean and median values for 1- and 5-year EDF are decreasing in firm size. In sum, the univariate results suggest that our sample user firms have lower default probabilities than non-users. This observation is consistent with the notion that the use of derivatives helps lowering the cost of equity capital by mitigating the financial distress risk. Table 9 shows that new user firms also experience significant mean and median reductions in their 1- and 5-year EDF values.

We now turn our attention to the pooled OLS regression results of the relation between 
firms' EDF and their use of derivative instruments in Table 10. In the model for 1-year EDF as the dependent variable, the derivatives use dummy appears to be statistically significant even at the $1 \%$ level and negatively associated with the probability of default. Specifically, the estimated coefficient of -0.0284 implies that derivatives user firms have a 2.84 percentage point lower probability of default in 1-year time as compared to non-users. Consistent with the finding of the univariate analysis in Table 6 , there is a significantly negative relation between firm's probability of default (in 1-year time) and its size. The estimated coefficients on other firm-level control variables also have their predicted signs and are statistically significant at the $1 \%$ or $5 \%$ level. We observe qualitatively similar results for the model utilizing 5 -year EDF as the dependent variable. Notably, the estimated coefficient of -0.0215 on the derivatives use dummy variable is significant at the 1\% level. Consistent with Brogaard, Li, and Xia (2017), the industry-adjusted leverage, equity volatility, and illiquidity are positively correlated with the probability of default. We also find similar results when we repeat the above pooled OLS regression analysis using lagged firm-level control variables.

Next, we estimate the EDF, derivatives use, and industry-adjusted leverage equations within a simultaneous equations framework. The parameter estimates are obtained using a two-stage procedure. In the first-stage, we separately run an OLS regression for the industry-adjusted leverage and a probit regression for the derivatives use decision. In the second stage, we estimate structural equations, in which the explanatory variables of concern are replaced with the predicted values from the first-stage regressions. Table 11 presents the results of this empirical examination. We find that our earlier results in Table 10 based on the pooled OLS regressions hold after accounting for potential endogeneity related to a firm's derivatives use and capital structure decisions. Importantly, we find that the probability of default in 1-year (5-year) time is negatively associated with derivatives use. For the 1-year (5-year) EDF model, our estimated coefficient of $-0.0239(-0.0223)$ on the derivatives use dummy variable is statistically significant at the $1 \%$ level. Finally, looking at the results based on the propensity score matching in Table 5, we find that firms that use derivatives have significantly lower EDF values than matched firms that do not. Taken altogether, these results show that our reasoning, due to the finding in Section 3.1, that derivatives hedging activities mitigate financial distress risk remain valid to the choice of alternative proxy for a firm's distress risk.

\section{Conclusion}

Despite the widespread use of derivatives for active corporate risk management, there is hardly any empirical evidence available regarding the impact of financial hedging on the cost of 
equity outside of a US setting. This paper examines the relation between firms' derivatives use and the cost of equity capital for a sample of German non-financial firms. We use hand-collected data on derivatives hedging and compute a firm's cost of equity capital based on the Fama and French (1993) three-factor model. Our univariate analysis shows that user firms experience, on average, 306 basis points lower cost of equity than non-users. When considering the industryadjusted estimate, derivatives users still enjoy, on average, a 109 basis point lower cost of equity. We also find that the reduction in the cost of equity of derivatives user firms is attributable to their lower market, size, and value factor betas. This observation is consistent with the notion that a firm's use of derivative instruments is associated with the lowering of financial distress risk and this distress risk has a systematic component, which is priced in the cross-section of stock returns. Subsequently, using a firm's expected default frequency as a proxy for financial distress, we support our evidence on the cost of equity capital by showing that derivatives use significantly reduces the likelihood of financial distress for German non-financial firms.

Our finding of a negative relation between derivatives use and the cost of equity capital remains robust to multivariate specifications and specifications that account for potential endogeneity arising from a firm's derivatives hedging and capital structure decisions. Our empirical analysis also reveals that the reduction in the cost of equity capital is largest for smaller firms and for firms that use foreign currency and interest rate derivative instruments. We find that new user firms experience a significant reduction in the cost of equity in the first year of adoption. The reduction in the cost of equity stems from lower exposures to the market, size, and value risk factors. In sum, our examination of the impact of derivatives use on the cost of equity provides useful insights for corporations wishing to use derivatives as a means of reducing their cost of financing capital.

\section{Appendix}

Tables A.1-A.4. 


\section{References}

Adam, Tim R., 2009, Capital expenditures, financial constraints, and the use of options, Journal of Financial Economics 92, 238-251.

— Sudipto Dasgupta, and Sheridan Titman, 2007, Financial constraints, competition, and hedging in industry equilibrium, Journal of Finance 62, 2445-2473.

Adam, Tim R., and Chitru S. Fernando, 2006, Hedging, speculation, and shareholder value, Journal of Financial Economics 81, 283-309.

Allayannis, George, Ugur Lel, and Darius P. Miller, 2012, The use of foreign currency derivatives, corporate governance, and firm value around the world, Journal of International Economics $87,65-79$.

Allayannis, George, and James P. Weston, 2001, The use of foreign currency derivatives and firm market value, Review of Financial Studies 14, 243-276.

Amihud, Yakov, 2002, Illiquidity and stock returns: Cross-section and time-series effects, Journal of Financial Markets 5, 31-56.

Ashbaugh, Hollis, Daniel W. Collins, and Ryan LaFond, 2004, Corporate governance and the cost of equity capital, Working Paper, University of Iowa.

Attig, Najah, Omrane Guedhami, and Dev Mishra, 2008, Multiple large shareholders, control contests, and implied cost of equity, Journal of Corporate Finance 14, 721-737.

Bartram, Söhnke M., Gregory W. Brown, and Jennifer Conrad, 2011, The effects of derivatives on firm risk and value, Journal of Financial and Quantitative Analysis 46, 967-999.

Bartram, Söhnke M., Gregory W. Brown, and Frank R. Fehle, 2009, International evidence on financial derivatives usage, Financial Management 38, 185-206.

Bessembinder, Hendrik, 1991, Forward contracts and firm value: Investment incentive and contracting effects, Journal of Financial and Quantitative Analysis 26, 519-532.

Bharath, Sreedhar T., and Tyler Shumway, 2008, Forecasting default with the Merton distance to default model, Review of Financial Studies 21, 1339-1369.

Block, Stanley B., and Timothy J. Gallagher, 1986, The use of interest rate futures and options by corporate financial managers, Financial Management 15, 73-78. 
Bodnar, Gordon M., and Günther Gebhardt, 1999, Derivatives usage in risk management by US and German non-financial firms: A comparative survey, Journal of International Financial Management and Accounting 10, 153-187.

Brogaard, Jonathan, Dan Li, and Ying Xia, 2017, Stock liquidity and default risk, Journal of Financial Economics 124, 486-502.

Campbell, John Y., Jens Hilscher, and Jan Szilagyi, 2008, In search of distress risk, Journal of Finance 63, 2899-2939.

Campello, Murillo, Chen Lin, Yue Ma, and Hong Zou, 2011, The real and financial implications of corporate hedging, Journal of Finance 66, 1615-1647.

Carter, David A., Daniel A. Rogers, and Betty J. Simkins, 2006, Does hedging affect firm value? Evidence from the US airline industry, Financial Management 35, 53-86.

Chen, Jun, and Tao-Hsien D. King, 2014, Corporate hedging and the cost of debt, Journal of Corporate Finance 29, 221-245.

Chod, Jiri, Nils Rudi, and Jan A. Van Mieghem, 2010, Operational flexibility and financial hedging: Complements or substitutes, Management Science 56, 1030-1045.

Davydenko, Sergei A., and Julian R. Franks, 2008, Do bankruptcy codes matter? A study of defaults in France, Germany, and the UK, Journal of Finance 63, 565-608.

DeAngelo, Harry, and Ronald W. Masulis, 1980, Optimal capital structure under corporate and personal taxation, Journal of Financial Economics 8, 3-29.

Dimson, Elroy, 1979, Risk measurement when shares are subject to infrequent trading, Journal of Financial Economics 7, 197-226.

Djankov, Simeon, Oliver Hart, Caralee McLiesh, and Andrei Shleifer, 2008, Debt enforcement around the world, Journal of Political Economy 116, 1105-1149.

Djankov, Simeon, Rafael La Porta, Florencio Lopez-de-Silanes, and Andrei Shleifer, 2008, The law and economics of self-dealing, Journal of Financial Economics 88, 430-465.

D’Mello, Ranjan, and Pervin K. Shroff, 2000, Equity undervaluation and decisions related to repurchase tender offers: An empirical investigation, Journal of Finance 55, 2399-2424.

Dyck, Alexander, and Luigi Zingales, 2004, Private benefits of control: An international comparison, Journal of Finance 59, 537-600. 
Fama, Eugene F., and Kenneth R. French, 1993, Common risk factors in the returns on stocks and bonds, Journal of Financial Economics 33, 3-56.

— , 1996, Multifactor explanations of asset pricing anomalies, Journal of Finance 51, $55-84$.

, 1997, Industry costs of equity, Journal of Financial Economics 43, 153-193.

— 2006, Profitability, investment and average returns, Journal of Financial Economics $82,491-518$.

Fauver, Larry, and Andy Naranjo, 2010, Derivative usage and firm value: The influence of agency costs and monitoring problems, Journal of Corporate Finance 16, 719-735.

Franks, Julian R., and Colin P. Mayer, 2001, Ownership and control of German corporations, Review of Financial Studies 14, 943-977.

Froot, Kenneth A., David S. Scharfstein, and Jeremy C. Stein, 1993, Risk management: Coordinating corporate investment and financing policies, Journal of Finance 48, 1629-1658.

Gay, Gerald D., Chen-Miao Lin, and Stephen D. Smith, 2011, Corporate derivatives use and the cost of equity, Journal of Banking \& Finance 35, 1491-1506.

Géczy, Christopher, Bernadette A. Minton, and Catherine Schrand, 1997, Why firms use currency derivatives, Journal of Finance 52, 1323-1354.

Gorton, Gary B., and Frank A. Schmid, 2000, Universal banking and the performance of German firms, Journal of Financial Economics 58, 29-80.

Graham, John R., and Daniel A. Rogers, 2002, Do firms hedge in response to tax incentives, Journal of Finance 57, 815-839.

Guay, Wayne R., and S. P. Kothari, 2003, How much do firms hedge with derivatives?, Journal of Financial Economics 70, 423-461.

Hail, Luzi, and Christian Leuz, 2006, International differences in the cost of equity capital: Do legal institutions and securities regulation matter?, Journal of Accounting Research 44, $485-531$.

Haushalter, David, Sandy Klasa, and William F. Maxwell, 2007, The influence of product market dynamics on a firm's cash holdings and hedging behavior, Journal of Financial Economics $84,797-825$. 
Jin, Yanbo, and Philippe Jorion, 2006, Firm value and hedging: Evidence from US oil and gas producers, Journal of Finance 61, 893-919.

La Porta, Rafael, Florencio Lopez-de-Silanes, and Andrei Shleifer, 2006, What works in securities laws?, Journal of Finance 61, 1-32.

, and Robert W. Vishny, 1998, Law and finance, Journal of Political Economy 106, $1113-1155$.

— , 1999, Corporate ownership around the world, Journal of Finance 54, 471-517.

Lang, Larry, Eli Ofek, and René M. Stulz, 1996, Leverage, investment, and firm growth, Journal of Financial Economics 40, 3-29.

Leland, Hayne E., 1998, Agency costs, risk management, and capital structure, Journal of Finance 53, 1213-1243.

Lin, Chen, Yue Ma, Paul Malatesta, and Yuhai Xuan, 2011, Ownership structure and the cost of corporate borrowing, Journal of Financial Economics 100, 1-23.

Lin, Chen-Miao, Richard D. Phillips, and Stephen D. Smith, 2008, Hedging, financing, and investment decisions: Theory and empirical tests, Journal of Banking ES Finance 32, 15661582.

Lombardo, Davide, and Marco Pagano, 2002, Law and equity markets: A simple model, in Joseph A. McCahery, Piet Moerland, Theo Raaijmakers, and Luc Renneboog, ed.: Convergence and Diversity of Corporate Governance Regimes and Capital Markets . pp. 343-362 (Oxford University Press: United Kingdom).

Merton, Robert C., 1974, On the pricing of corporate debt: The risk structure of interest rates, Journal of Finance 29, 449-470.

Modigliani, Franco, and Merton H. Miller, 1958, The cost of capital, corporation finance and the theory of investment, American Economic Review 48, 261-297.

Myers, Stewart C., 1977, Determinants of corporate borrowing, Journal of Financial Economics $5,147-175$.

Pérez-González, Francisco, and Hayong Yun, 2013, Risk management and firm value: Evidence from weather derivatives, Journal of Finance 68, 2143-2176. 
Purnanandam, Amiyatosh, 2008, Financial distress and corporate risk management: Theory and evidence, Journal of Financial Economics 87, 706-739.

Rampini, Adriano A., and S. Viswanathan, 2010, Collateral, risk management, and the distribution of debt capacity, Journal of Finance 65, 2293-2322.

Schrimpf, Andreas, Michael Schröder, and Richard Stehle, 2007, Cross-sectional tests of conditional asset pricing models: Evidence from the German stock market, European Financial Management 13, 880-907.

Shleifer, Andrei, and Robert W. Vishny, 1997, The limits of arbitrage, Journal of Finance 52, $35-55$.

Smith, Clifford W. Jr., and Renè M. Stulz, 1985, The determinants of firms' hedging policies, Journal of Financial and Quantitative Analysis 20, 391-405.

Stulz, Renè M., 1986, Asset pricing and expected inflation, Journal of Finance 41, 209-223.

Titman, Sheridan, and Roberto Wessels, 1988, The determinants of capital structure choice, Journal of Finance 43, 1-19.

Vassalou, Maria, and Yuhang Xing, 2004, Default risk in equity returns, Journal of Finance 59, $831-868$.

Warner, Jerold B., 1977, Bankruptcy costs: Some evidence, Journal of Finance 32, 337-347. 
Table 1

Institutional characteristics

The table reports some key country-specific institutional characteristics. Widely held indicates the proportion of firms that are owned by large number of shareholders and not restricted to handful of shareholders. Columns 1 and 2 showing proportions, respectively, for large and medium size firms are sourced from La Porta, Lopez-de-Silanes, Shleifer, and Vishny (1999). Column 3 shows the index of shareholder rights, which ranges between zero and five, and is sourced from La Porta, Lopez-de-Silanes, Shleifer, and Vishny (1998). Column 4 shows the quality of shareholder right enforcement, which is the average of ex ante and ex post private control of self-dealing. Column 5 shows the index of equity disclosure, which is the arithmetic average of compensation, prospectus, shareholders, inside ownership, contracts irregular, and transactions. Country-specific institutional characteristics reported in columns 4 and 5 are, respectively, sourced from Djankov, La Porta, Lopez-de-Silanes, and Shleifer (2008) and La Porta, Lopez-de-Silanes, and Shleifer (2006). Column 6 shows the first-year corporate effective tax rate (in \%). Column 7 reports the bankruptcy efficiency, which is the present value of the terminal value of the firm after bankruptcy costs. Country-specific institutional characteristics reported in columns 6 and 7 are sourced from Djankov, Hart, McLiesh, and Shleifer (2008). Column 8 reports the block premium, which is the difference between the price per share for the control block at announcement day $t$ and the price on the Exchange at day $t+2$, divided by the price on the Exchange after the announcement and multiplied by the proportion of cash flow rights in the controlling block. Block premia reported in column 8 are sourced from Dyck and Zingales (2004).

\begin{tabular}{|c|c|c|c|c|c|c|c|c|}
\hline & \multicolumn{2}{|c|}{ Widely held } & \multirow{2}{*}{$\begin{array}{l}\text { Shareholder } \\
\text { rights } \\
(3)\end{array}$} & \multirow{2}{*}{$\begin{array}{l}\text { Shareholder right } \\
\text { enforcement } \\
\text { (4) }\end{array}$} & \multirow{2}{*}{$\begin{array}{l}\text { Equity } \\
\text { disclosure } \\
\text { (5) }\end{array}$} & \multirow{2}{*}{$\begin{array}{l}\text { Tax } \\
\text { rate } \\
(6)\end{array}$} & \multirow{2}{*}{$\begin{array}{l}\text { Bankruptcy } \\
\text { efficiency } \\
\text { (7) }\end{array}$} & \multirow{2}{*}{$\begin{array}{l}\text { Block } \\
\text { premium } \\
(8)\end{array}$} \\
\hline & $\begin{array}{l}\text { Large } \\
(1)\end{array}$ & $\begin{array}{l}\text { Medium } \\
(2)\end{array}$ & & & & & & \\
\hline Germany & 0.50 & 0.10 & 1 & 0.28 & 0.42 & 23.50 & 57.00 & 0.10 \\
\hline United States & 0.80 & 0.90 & 5 & 0.65 & 1.00 & 18.19 & 85.80 & 0.01 \\
\hline
\end{tabular}


Table 2

\section{Univariate comparison of derivatives users and non-users}

The table reports mean and median values of the cost of equity, industry-adjusted cost of equity, and market, small-minus-big (SMB), and high-minus-low (HML) factor betas, and expected default frequency (EDF) for a sample of derivatives user and non-user German non-financial firms. The cost of equity of a firm is computed as the difference between its expected return and the risk-free rate using the Fama and French (1993) three-factor model. The industry-adjusted cost of equity of a firm is obtained as the difference between its estimated cost of equity and the median industry estimate for a given year. Market, SMB, and HML betas are the betas, respectively, related to the market risk premium, and SMB and HML risk factors. 1-year (5-year) EDF is the probability that a firm will default in 1-year (5-year) time. N is the number of firm-year observations. * $* *$, and ${ }^{* * *}$ denote statistical significance at the $10 \%, 5 \%$, and $1 \%$ levels, respectively. The sample period is from 1999 to 2009 .

\begin{tabular}{|c|c|c|c|c|c|c|c|c|c|c|c|}
\hline \multirow[t]{2}{*}{ Variable } & \multicolumn{3}{|c|}{ All firms } & \multicolumn{3}{|c|}{ Derivatives users } & \multicolumn{3}{|c|}{ Derivatives non-users } & \multicolumn{2}{|c|}{ Difference tests } \\
\hline & $\mathrm{N}$ & Mean & Median & $\mathrm{N}$ & Mean & Median & $\mathrm{N}$ & Mean & Median & $\begin{array}{l}\text { Mean } \\
t \text {-test }\end{array}$ & $\begin{array}{l}\text { Median } \\
\text { Wilcoxon test }\end{array}$ \\
\hline Cost of equity & 1984 & 0.0856 & 0.0851 & 1388 & 0.0765 & 0.0761 & 596 & 0.1070 & 0.1060 & $-0.0306^{* * *}$ & $-0.0299^{* * *}$ \\
\hline Market beta & 1984 & 0.9041 & 0.9398 & 1388 & 0.8128 & 0.8334 & 596 & 1.1169 & 1.1876 & $-0.3040^{* * *}$ & $-0.3542^{* * *}$ \\
\hline SMB beta & 1984 & 0.6133 & 0.5668 & 1388 & 0.5023 & 0.4543 & 596 & 0.8718 & 0.8289 & $-0.3695^{* * *}$ & $-0.3746^{* *}$ \\
\hline HML beta & 1984 & 0.3480 & 0.3337 & 1388 & 0.3289 & 0.3310 & 596 & 0.3922 & 0.3401 & $-0.0633^{* *}$ & $-0.0092^{*}$ \\
\hline
\end{tabular}


Table 3

\section{Derivatives use and the industry-adjusted cost of equity: Pooled OLS regressions}

The table reports the pooled ordinary least squares (OLS) regression results of the relation between a sample of German non-financial firms' industry-adjusted cost of equity and their use of derivatives. The dependent variable is the industry-adjusted cost of equity. Derivatives use is a dummy variable that takes the value 1 if a firm reports the use of any type of derivatives (i.e., foreign currency, interest rate, or commodity derivatives) and zero otherwise. The industry-adjusted leverage of a firm is computed as the difference between its leverage, measured as the ratio of long-term debt plus the current portion of long-term debt to total assets, and the median industry leverage for a given year. Book-to-market is the ratio of the book value of a firm's common stock to its market value. Illiquidity is the Amihud (2002) measure of illiquidity, obtained as the ratio of the absolute value of the daily stock return to the daily euro trading volume of the stock, averaged over all trading days (with non-zero volume) in a given year. Size is the natural logarithm of total assets. Number of segments is the number of business segments in which a firm operates. Ownership30 takes the value 1 if a firm's blockholder ownership is between $10 \%$ and $30 \%$ and zero otherwise. Ownership $30^{+}$takes the value 1 if a firm's blockholder ownership is above $30 \%$ and zero otherwise. The ratio of each segment sales to total sales is also incorporated in the pooled OLS regressions. Numbers in parentheses are standard errors corrected for simultaneous clustering on firm and year. Model 1 excludes the blockholder ownership dummy variables, whereas model 2 includes them. $*$, **, and ${ }^{* *}$ denote statistical significance at the $10 \%, 5 \%$, and $1 \%$ levels, respectively. See also notes to Table 2.

\begin{tabular}{lll}
\hline & Model 1 & Model 2 \\
\hline Intercept & $0.0281^{* * *}$ & $0.0273^{* * *}$ \\
Derivatives use & $(0.0074)$ & $(0.0077)$ \\
& $-0.0160^{* * *}$ & $-0.0139^{* * *}$ \\
Industry-adjusted leverage & $(0.0025)$ & $(0.0024)$ \\
& $0.0499^{* * *}$ & $0.0562^{* * *}$ \\
Book-to-market & $(0.0033)$ & $(0.0041)$ \\
& $0.0704^{* * *}$ & $0.0640^{* * *}$ \\
Illiquidity & $(0.0086)$ & $(0.0091)$ \\
& $0.0411^{* * *}$ & $0.0365^{* * *}$ \\
Size & $(0.0074)$ & $(0.0073)$ \\
& $-0.0389^{* * *}$ & $-0.0370^{* * *}$ \\
Number of segments & $(0.0082)$ & $(0.0077)$ \\
& -0.0030 & -0.0033 \\
Ownership30 & $(0.0020)$ & $(0.0021)$ \\
& & -0.0069 \\
Ownership30 & & $(0.0102)$ \\
& & $-0.0183^{* * *}$ \\
Number of observations & 1855 & $(0.0053)$ \\
Number of derivatives users & 1331 & \\
Number of derivatives non-users & 524 & \\
Adjusted $R^{2}$ & 0.0441 & 0.0549 \\
& &
\end{tabular}




\section{Table 4}

\section{Derivatives use and the industry-adjusted cost of equity: Simultaneous equations analysis}

The table reports results of the relation between firms' industry-adjusted cost of equity, derivatives use, and industry-adjusted leverage, estimated within a simultaneous equations framework. In the first stage, an ordinary least squares (OLS) regression for the industry-adjusted leverage and a probit regression for the derivatives use decision are run separately. In the second stage, a structural equation is estimated where the relevant explanatory variables are replaced with the predicted values from the first-stage regressions. Quick ratio is the ratio of cash and short-term investments to current liabilities. Foreign sales to net sales is the percentage of foreign sales to net sales. Property, plant, and equipment is the ratio of property, plant, and equipment to total assets. Depreciation is the ratio of depreciation expenses to total assets. Return on assets is computed as the ratio of income before extraordinary items to total assets. SGA expenses are computed as the ratio of selling, general, and administrative expenses to net sales. The regressions also include the ratio of each segment sales to total sales as well as year dummies to control for industry and time effects. Numbers in parentheses are standard errors. See also notes to Tables 2 and 3.

\begin{tabular}{llll}
\hline $\begin{array}{l}\text { Dependent variable: } \\
\text { Variable/estimation method }\end{array}$ & $\begin{array}{l}\text { Cost of equity } \\
\text { OLS }\end{array}$ & $\begin{array}{l}\text { Derivatives } \\
\text { Probit }\end{array}$ & $\begin{array}{l}\text { Leverage } \\
\text { OLS }\end{array}$ \\
\hline \multirow{2}{*}{ Intercept } & & & \\
& $\begin{array}{l}0.0315^{* *} \\
(0.0127)\end{array}$ & $-1.7747^{* * *}$ & $0.0588^{*}$ \\
& & $(0.3628)$ & $(0.0314)$
\end{tabular}

Endogenous variables

Derivatives use

Industry-adjusted leverage

Exogenous variables

Book-to-market

Illiquidity

Size

Number of segments

Quick ratio

Foreign sales to net sales

Property, plant, and equipment

Depreciation

Return on assets

SGA expenses

Ownership30

Ownership $30^{+}$

Number of observations

Number of derivatives users

Number of derivatives non-users Adjusted $R^{2}$

Log-likelihood

Sargan-Hansen $J$-test ( $p$-value)

$\begin{array}{ll}-0.0236^{* * *} & \\ (0.0095) & \\ 0.1240^{* * *} & 0.2406^{* * *} \\ (0.0058) & (0.0558)\end{array}$

$0.0446^{* * *}$

(0.0191)

$0.0640^{* * *}$
$(0.0160)$
$0.0406^{* * *}$
$(0.0152)$
$-0.0997^{* * *}$
$(0.0199)$
-0.0037
$(0.0033)$

$-0.1883$

$(0.1526)$

$0.0559 * * *$

(0.0171)

$0.4840 * * * \quad 0.0373 * * *$

$(0.0783) \quad(0.0045)$

$-0.0056$

(0.0071)

$-0.0693^{* *}$ (0.0321)

$1.6216^{* * *}$

(0.3375)

$0.2363^{* * *}$

(0.0424)

$-0.4206^{*}$

$(0.2216)$

$-0.1460^{* *}$

(0.0626)

$-0.0686$

(0.0494)

$-0.0103$

$-0.0187$

0.0277

(0.0124)

$0.0198)$

$-0.0265^{* *}$

0.0179

(0.0135)

$0.0399^{* *}$

0.0216

1855

1331

524

0.0943

0.1296 
Table 5

Matched-sample tests

The table reports mean and median values of the cost of equity, industry-adjusted cost of equity, and market, small-minus-big (SMB), and high-minus-low (HML) factor betas, and expected default frequency (EDF) for a sample of derivatives user and non-user German non-financial firms matched on the basis of their (estimated) propensity to use derivatives. The predicted probabilities (propensity scores) of derivatives use are computed using the probit model specified by equation (4). See also notes to Table 2 .

\begin{tabular}{|c|c|c|c|c|c|c|c|}
\hline \multirow[t]{2}{*}{ Variable } & \multirow[b]{2}{*}{$\mathrm{N}$} & \multicolumn{2}{|c|}{ Derivatives users } & \multicolumn{2}{|c|}{ Derivatives non-users } & \multicolumn{2}{|c|}{ Difference tests } \\
\hline & & Mean & Median & Mean & Median & $\begin{array}{l}\text { Mean } \\
t \text {-test }\end{array}$ & $\begin{array}{l}\text { Median } \\
\text { Wilcoxon test }\end{array}$ \\
\hline Cost of equity & 341 & 0.0829 & 0.0847 & 0.0940 & 0.0962 & $-0.0111^{* * *}$ & $-0.0115^{* * *}$ \\
\hline Industry-adjusted cost of equity & 341 & 0.0063 & 0.0071 & 0.0138 & 0.0154 & $-0.0075^{* * *}$ & $-0.0083^{* * *}$ \\
\hline Market beta & 341 & 0.9311 & 0.9324 & 1.0493 & 1.0521 & $-0.1182^{* * *}$ & $-0.1197^{* * *}$ \\
\hline SMB beta & 341 & 0.4955 & 0.5136 & 0.5813 & 0.5989 & $-0.0858^{* * *}$ & $-0.0853^{* * *}$ \\
\hline HML beta & 341 & 0.2481 & 0.2516 & 0.2899 & 0.2977 & $-0.0418^{* * *}$ & $-0.0461^{* * *}$ \\
\hline 1-year EDF & 341 & 0.0056 & 0.0057 & 0.0174 & 0.0183 & $-0.0118^{* * *}$ & $-0.0126^{* * *}$ \\
\hline 5-year EDF & 341 & 0.0060 & 0.0063 & 0.0182 & 0.0189 & $-0.0122^{* * *}$ & $-0.0126^{* * *}$ \\
\hline
\end{tabular}


Table 6

Univariate comparison of derivatives users and non-users: Size terciles

The table reports mean and median values of the cost of equity, industry-adjusted cost of equity, and market, small-minus-big (SMB), and high-minus-low (HML) factor betas, and expected default frequency (EDF) for a sample of derivatives user and non-user German non-financial firms broken down into size terciles. In Panel A, tercile 1 contains 666 firm-year observations of which 203 report using derivatives and 463 report non-use. In Panel B, tercile 2 contains 660 firm-year observations of which 583 report using derivatives and 77 report non-use. In Panel C, tercile 3 contains 658 firm-year observations of which 602 report using derivatives and 56 report non-use. See also notes to Table 2.

\begin{tabular}{|c|c|c|c|c|c|c|c|c|}
\hline \multirow[t]{2}{*}{ Variable } & \multicolumn{2}{|c|}{ All firms } & \multicolumn{2}{|c|}{ Derivatives users } & \multicolumn{2}{|c|}{ Derivatives non-users } & \multicolumn{2}{|c|}{ Difference tests } \\
\hline & Mean & Median & Mean & Median & Mean & Median & Mean & Median \\
\hline
\end{tabular}

Panel A: Tercile 1 (the smallest $1 / 3$ of the sample firms)

$\begin{array}{lllllllll}\text { Cost of equity } & 0.1053 & 0.1049 & 0.0889 & 0.0902 & 0.1126 & 0.1113 & -0.0237^{* * *} & -0.0211^{* * *} \\ \text { Industry-adjusted cost of equity } & 0.0124 & 0.0135 & 0.0059 & 0.0063 & 0.0153 & 0.0167 & -0.0094^{* * *} & -0.0104^{* * *} \\ \text { Market beta } & 1.1521 & 1.2285 & 1.0523 & 1.0989 & 1.1959 & 1.2853 & -0.1436^{* * *} & -0.1864^{* * *} \\ \text { SMB beta } & 0.8010 & 0.7490 & 0.5423 & 0.4889 & 0.9144 & 0.8631 & -0.3721^{* * *} & -0.3742^{* * *} \\ \text { HML beta } & 0.3725 & 0.3300 & 0.3172 & 0.3278 & 0.3968 & 0.3310 & -0.0796^{* * *} & -0.0032^{*} \\ \text { 1-year EDF } & 0.0185 & 0.0235 & 0.0107 & 0.0130 & 0.0219 & 0.0281 & -0.0112^{* * *} & -0.0151^{* * *} \\ \text { 5-year EDF } & 0.0194 & 0.0247 & 0.0123 & 0.0137 & 0.0225 & 0.0299 & -0.0102^{* * *} & -0.0162^{* * *}\end{array}$

Panel B: Tercile 2 (the middle $1 / 3$ of the sample firms)

\begin{tabular}{|c|c|c|c|c|c|c|c|c|}
\hline Cost of equity & 0.0829 & 0.0829 & 0.0812 & 0.0811 & 0.0953 & 0.0960 & $-0.0141^{* * *}$ & $-0.0149^{* *}$ \\
\hline Industry-adjusted cost of equity & 0.0048 & 0.0043 & 0.0041 & 0.0036 & 0.0102 & 0.0096 & $-0.0061^{* *}$ & $-0.0060^{* *}$ \\
\hline Market beta & 0.8635 & 0.8910 & 0.8551 & 0.8812 & 0.9273 & 0.9650 & $-0.0722^{* * *}$ & $-0.0838^{* * *}$ \\
\hline SMB beta & 0.5485 & 0.4919 & 0.5217 & 0.4613 & 0.7513 & 0.7234 & $-0.2296^{* * *}$ & $-0.2621 * * *$ \\
\hline HML beta & 0.3683 & 0.3748 & 0.3619 & 0.3700 & 0.4164 & 0.4109 & -0.0545 & -0.0409 \\
\hline 1-year EDF & 0.0111 & 0.0083 & 0.0100 & 0.0075 & 0.0198 & 0.0146 & $-0.0098^{* *}$ & $-0.0071^{* *}$ \\
\hline 5-year EDF & 0.0118 & 0.0096 & 0.0107 & 0.0087 & 0.0200 & 0.0165 & $-0.0093^{* *}$ & $-0.0078^{* *}$ \\
\hline \multicolumn{9}{|c|}{ Panel C: Tercile 3 (the largest $1 / 3$ of the sample firms) } \\
\hline Cost of equity & 0.0685 & 0.0673 & 0.0677 & 0.0665 & 0.0773 & 0.0754 & $-0.0096^{* *}$ & $-0.0089^{*}$ \\
\hline Industry-adjusted cost of equity & -0.0012 & 0.0002 & -0.0011 & 0.0002 & -0.0018 & 0.0007 & 0.0007 & -0.0005 \\
\hline Market beta & 0.6939 & 0.6966 & 0.6911 & 0.6976 & 0.7240 & 0.6861 & -0.0329 & 0.0115 \\
\hline SMB beta & 0.4884 & 0.4576 & 0.4701 & 0.4539 & 0.6851 & 0.6911 & -0.2150 & -0.2252 \\
\hline HML beta & 0.3027 & 0.2962 & 0.3010 & 0.2942 & 0.3214 & 0.3181 & $-0.0204^{*}$ & $-0.0239^{*}$ \\
\hline 1-year EDF & 0.0073 & 0.0024 & 0.0071 & 0.0021 & 0.0095 & 0.0051 & $-0.0024^{*}$ & $-0.0030^{*}$ \\
\hline 5-year EDF & 0.0084 & 0.0031 & 0.0083 & 0.0029 & 0.0100 & 0.0053 & $-0.0017^{*}$ & $-0.0024^{*}$ \\
\hline
\end{tabular}


Table 7

Derivatives use and the industry-adjusted cost of equity: Pooled OLS regressions for size terciles

The table reports the pooled ordinary least squares (OLS) regression results of the relation between a sample of German non-financial firms' industry-adjusted cost of equity and their use of derivatives broken down into size terciles. The dependent variable is the industry-adjusted cost of equity. Numbers in parentheses are standard errors corrected for simultaneous clustering on firm and year. See also notes to Tables 2 and 3.

\begin{tabular}{|c|c|c|c|}
\hline & Tercile 1 & Tercile 2 & Tercile 3 \\
\hline Intercept & $\begin{array}{l}0.0245^{* * *} \\
(0.0057)\end{array}$ & $\begin{array}{l}0.0031 \\
(0.0086)\end{array}$ & $\begin{array}{c}-0.0074 \\
(0.0094)\end{array}$ \\
\hline Derivatives use & $\begin{array}{l}-0.0215^{* * *} \\
(0.0082)\end{array}$ & $\begin{array}{l}-0.0111 \\
(0.0084)\end{array}$ & $\begin{array}{l}-0.0026 \\
(0.0070)\end{array}$ \\
\hline Industry-adjusted leverage & $\begin{array}{l}0.0311^{* * *} \\
(0.0085)\end{array}$ & $\begin{array}{l}0.0321^{* * *} \\
(0.0120)\end{array}$ & $\begin{array}{l}0.0167^{*} \\
(0.0101)\end{array}$ \\
\hline Book-to-market & $\begin{array}{l}0.0240 * * \\
(0.0101)\end{array}$ & $\begin{array}{l}0.0250^{* *} \\
(0.0107)\end{array}$ & $\begin{array}{l}0.0161 * * * \\
(0.0052)\end{array}$ \\
\hline Illiquidity & $\begin{array}{l}0.0472^{* * *} \\
(0.0160)\end{array}$ & $\begin{array}{l}0.0132^{* * *} \\
(0.0038)\end{array}$ & $\begin{array}{l}0.0126^{* *} \\
(0.0060)\end{array}$ \\
\hline Number of segments & $\begin{array}{l}-0.0040 \\
(0.0057)\end{array}$ & $\begin{array}{l}-0.0033 \\
(0.0046)\end{array}$ & $\begin{array}{l}-0.0037 \\
(0.0050)\end{array}$ \\
\hline Ownership30 & $\begin{array}{l}-0.0054 \\
(0.0127)\end{array}$ & $\begin{array}{l}-0.0047 \\
(0.0120)\end{array}$ & $\begin{array}{l}0.0016 \\
(0.0119)\end{array}$ \\
\hline Ownership30 ${ }^{+}$ & $\begin{array}{l}-0.0143^{* *} \\
(0.0067)\end{array}$ & $\begin{array}{l}-0.0150^{* *} \\
(0.0075)\end{array}$ & $\begin{array}{l}0.0027 \\
(0.0076)\end{array}$ \\
\hline Number of observations & 621 & 618 & 616 \\
\hline Number of derivatives users & 178 & 570 & 592 \\
\hline Number of derivatives non-users & 443 & 48 & 24 \\
\hline Adjusted $R^{2}$ & 0.0985 & 0.0731 & 0.0675 \\
\hline
\end{tabular}




\section{Table 8}

\section{Type of derivatives use and the industry-adjusted cost of equity}

The table reports the pooled ordinary least squares (OLS) regression results of the relation between a sample of German non-financial firms' industry-adjusted cost of equity and the type of derivatives use. The dependent variable is the industry-adjusted cost of equity. Currency is a dummy variable that takes the value 1 if a firm reports the use of foreign currency derivatives and zero otherwise. Interest is a dummy variable that takes the value 1 if a firm reports the use of interest rate derivatives and zero otherwise. Commodity is a dummy variable that takes the value 1 if a firm reports the use of commodity derivatives and zero otherwise. The ratio of each segment sales to total sales is also incorporated in the pooled OLS regression. Numbers in parentheses are standard errors corrected for simultaneous clustering on firm and year. See also notes to Tables 2 and 3.

\begin{tabular}{ll}
\hline & $0.0210^{* * *}$ \\
Intercept & $(0.0063)$ \\
Currency & $-0.0094^{* * *}$ \\
& $(0.0025)$ \\
Interest & $-0.0032^{* *}$ \\
& $(0.0014)$ \\
Commodity & -0.0016 \\
& $(0.0016)$ \\
Industry-adjusted leverage & $0.0320^{* * *}$ \\
& $(0.0057)$ \\
Book-to-market & $0.0626^{* * *}$ \\
& $(0.0130)$ \\
Illiquidity & $0.0417^{* * *}$ \\
& $(0.0072)$ \\
Size & $-0.0345^{* * *}$ \\
& $(0.0097)$ \\
Number of segments & -0.0029 \\
& $(0.0021)$ \\
Ownership30 & -0.0072 \\
& $(0.0135)$ \\
Ownership30 & $-0.0195^{* * *}$ \\
& $(0.0069)$ \\
Number of observations & 1855 \\
Number of derivatives users & 1331 \\
Number of derivatives non-users & 524 \\
Adjusted $R^{2}$ & 0.0509 \\
& \\
&
\end{tabular}


Table 9

Changes in the cost of equity and risk characteristics of new users of derivatives

The table reports changes in the cost of equity, industry-adjusted cost of equity, and market, small-minus-big (SMB), and high-minus-low (HML) factor betas, and expected default frequency (EDF) for a sample of 86 German non-financial firms that initiated derivatives programs during the sample period. A firm is categorized as a new user of derivatives if it reports derivatives use in year $t$, but does not report a position in derivatives prior to year $t$. See also notes to Table 2 .

\begin{tabular}{llll}
\hline Variable & Mean change & Median change & Std. dev. \\
\hline & & & \\
Cost of equity & $-0.0246^{* * *}$ & $-0.0253^{* * *}$ & 0.0175 \\
Industry-adjusted cost of equity & $-0.0286^{* * *}$ & $-0.0287^{* * *}$ & 0.0151 \\
Market beta & $-0.0750^{* * *}$ & $-0.0778^{* * *}$ & 0.1248 \\
SMB beta & $-0.0192^{* * *}$ & $-0.0185^{* * *}$ & 0.0347 \\
HML beta & $-0.0209^{* *}$ & $-0.0227^{* *}$ & 0.0932 \\
1-year EDF & $-0.0193^{* *}$ & $-0.0205^{* *}$ & 0.0888 \\
5-year EDF & $-0.0155^{* *}$ & $-0.0179^{* *}$ & 0.0721 \\
& & & \\
\hline
\end{tabular}




\section{Table 10}

\section{Derivatives use and EDF: Pooled OLS regressions}

The table reports the pooled ordinary least squares (OLS) regression results of the relation between a sample of German non-financial firms' expected default frequency (EDF) and their use of derivatives. The regression in column 1 considers 1-year EDF as the dependent variable, while the regression in column 2 considers 5 -year $\mathrm{EDF}$ as the dependent variable. Equity volatility of a firm is first computed as the standard deviation over one year of daily returns and subsequently annualized by multiplying by $\sqrt{252}$. Excess return is calculated as the stock $i$ 's annual return minus the annual return on the value-weighted market portfolio. Numbers in parentheses are standard errors corrected for simultaneous clustering on firm and year. See also notes to Tables 2 through 4.

\begin{tabular}{lll}
\hline & 1 -year EDF & 5-year EDF \\
\hline Intercept & $0.0317^{* * *}$ & $0.0306^{* * *}$ \\
& $(0.0060)$ & $(0.0042)$ \\
Derivatives use & $-0.0284^{* * *}$ & $-0.0215^{* * *}$ \\
& $(0.0016)$ & $(0.0014)$ \\
Industry-adjusted leverage & $0.0243^{* * *}$ & $0.0230^{* * *}$ \\
& $(0.0047)$ & $(0.0036)$ \\
Return on assets & $-0.0212^{* * *}$ & $-0.0205^{* * *}$ \\
& $(0.0072)$ & $(0.0061)$ \\
Excess return & $-0.0108^{* * *}$ & $-0.0096^{* * *}$ \\
& $(0.0013)$ & $(0.0010)$ \\
Quick ratio & $-0.0022^{* * *}$ & $-0.0019^{* * *}$ \\
Size & $(0.0005)$ & $(0.0004)$ \\
& $-0.0259^{* * *}$ & $-0.0318^{* * *}$ \\
Equity volatility & $(0.0028)$ & $(0.0021)$ \\
& $0.0013^{* * *}$ & $0.0011^{* * *}$ \\
Illiquidity & $(0.0001)$ & $(0.0001)$ \\
Number of observations & $0.0633^{* *}$ & $0.0489^{* * *}$ \\
Number of derivatives users & $(0.0273)$ & $(0.0185)$ \\
Number of derivatives non-users & 1855 & \\
Adjusted $R^{2}$ & 1331 & \\
& 524 & \\
& 0.3803 & 0.4367 \\
& & \\
& & \\
& &
\end{tabular}




\section{Table 11}

\section{Derivatives use and EDF: Simultaneous equations analysis}

The table reports results of the relation between firms' 1-year (5-year) expected default frequency (EDF), derivatives use, and industry-adjusted leverage, estimated within a simultaneous equations framework. In the first stage, an ordinary least squares (OLS) regression for the industry-adjusted leverage and a probit regression for the derivatives use decision are run separately. In the second stage, structural equations are estimated where the relevant explanatory variables are replaced with the predicted values from the first-stage regressions. Numbers in parentheses are standard errors. See also notes to Tables 2 through 4 and 10.

\begin{tabular}{|c|c|c|c|c|}
\hline $\begin{array}{l}\text { Dependent variable: } \\
\text { Variable/estimation method }\end{array}$ & $\begin{array}{l}\text { 1-year EDF } \\
\text { OLS }\end{array}$ & $\begin{array}{l}\text { 5-year EDF } \\
\text { OLS }\end{array}$ & $\begin{array}{l}\text { Derivatives } \\
\text { Probit }\end{array}$ & $\begin{array}{l}\text { Leverage } \\
\text { OLS }\end{array}$ \\
\hline Intercept & $\begin{array}{l}0.0343^{* *} \\
(0.0171)\end{array}$ & $\begin{array}{l}0.0351^{* *} \\
(0.0179)\end{array}$ & $\begin{array}{l}-1.7374^{* * *} \\
(0.3579)\end{array}$ & $\begin{array}{l}0.0764^{*} \\
(0.0393)\end{array}$ \\
\hline \multicolumn{5}{|l|}{ Endogenous variables } \\
\hline Derivatives use & $\begin{array}{l}-0.0293^{* * *} \\
(0.0066)\end{array}$ & $\begin{array}{l}-0.0223^{* * *} \\
(0.0060)\end{array}$ & & $\begin{array}{l}0.0434^{* * *} \\
(0.0178)\end{array}$ \\
\hline Industry-adjusted leverage & $\begin{array}{l}0.0797^{* * *} \\
(0.0089)\end{array}$ & $\begin{array}{l}0.0737^{* * * *} \\
(0.0059)\end{array}$ & $\begin{array}{l}0.2331^{* * *} \\
(0.0631)\end{array}$ & \\
\hline \multicolumn{5}{|l|}{ Exogenous variables } \\
\hline Return on assets & $\begin{array}{l}-0.0214^{* * *} \\
(0.0072)\end{array}$ & $\begin{array}{l}-0.0207^{* * *} \\
(0.0061)\end{array}$ & & $\begin{array}{l}-0.1498^{* *} \\
(0.0630)\end{array}$ \\
\hline Excess return & $\begin{array}{l}-0.0198^{* * *} \\
(0.0017)\end{array}$ & $\begin{array}{l}-0.0176^{* * *} \\
(0.0019)\end{array}$ & & \\
\hline Quick ratio & $\begin{array}{l}-0.0019^{* * *} \\
(0.0006)\end{array}$ & $\begin{array}{l}-0.0016^{* * *} \\
(0.0005)\end{array}$ & $\begin{array}{l}-0.0733^{* *} \\
(0.0343)\end{array}$ & \\
\hline Size & $\begin{array}{l}-0.0387^{* * *} \\
(0.0088)\end{array}$ & $\begin{array}{l}-0.0405^{* * *} \\
(0.0074)\end{array}$ & $\begin{array}{l}0.4764^{* * *} \\
(0.0769)\end{array}$ & $\begin{array}{l}0.0424^{* * *} \\
(0.0045)\end{array}$ \\
\hline Equity volatility & $\begin{array}{l}0.0016^{* * *} \\
(0.0001)\end{array}$ & $\begin{array}{l}0.0012^{* * * *} \\
(0.0001)\end{array}$ & & \\
\hline Illiquidity & $\begin{array}{l}0.0669^{* *} \\
(0.0294)\end{array}$ & $\begin{array}{l}0.0521^{* * *} \\
(0.0204)\end{array}$ & & \\
\hline Book-to-market & & & $\begin{array}{l}-0.1943 \\
(0.1534)\end{array}$ & $\begin{array}{l}0.0736^{* * *} \\
(0.0165)\end{array}$ \\
\hline Number of segments & & & $\begin{array}{l}-0.0055 \\
(0.0059)\end{array}$ & \\
\hline Foreign sales to net sales & & & $\begin{array}{l}1.6470^{\text {*** }} \\
(0.3145)\end{array}$ & \\
\hline Property, plant, and equipment & & & & $\begin{array}{l}0.2320^{* * *} \\
(0.0434)\end{array}$ \\
\hline Depreciation & & & & $\begin{array}{l}-0.4462^{* *} \\
(0.2211)\end{array}$ \\
\hline SGA expenses & & & & $\begin{array}{l}-0.0684 \\
(0.0498)\end{array}$ \\
\hline Number of observations & 1855 & & & \\
\hline Number of derivatives users & 1331 & & & \\
\hline Number of derivatives non-users & 524 & & & \\
\hline Adjusted $R^{2}$ & 0.4551 & 0.4595 & & 0.1289 \\
\hline Log-likelihood & & & -780.2712 & \\
\hline Sargan-Hansen $J$-test ( $p$-value) & 0.2629 & 0.2682 & & \\
\hline
\end{tabular}


Table A.1

Descriptive statistics

The table reports descriptive statistics for characteristics of a sample of derivatives user and non-user German non-financial firms used in the empirical analysis. The sample period is from 1999 to 2009. See also notes to Tables 2 through 4 and 10.

\begin{tabular}{|c|c|c|c|c|c|c|c|c|c|c|c|}
\hline \multirow[t]{2}{*}{ Variable } & \multicolumn{3}{|c|}{ All firms } & \multicolumn{3}{|c|}{ Derivatives users } & \multicolumn{3}{|c|}{ Derivatives non-users } & \multicolumn{2}{|c|}{ Difference tests } \\
\hline & $\mathrm{N}$ & Mean & Median & $\mathrm{N}$ & Mean & Median & $\mathrm{N}$ & Mean & Median & $\begin{array}{l}\text { Mean } \\
t \text {-test }\end{array}$ & $\begin{array}{l}\text { Median } \\
\text { Wilcoxon test }\end{array}$ \\
\hline Industry-adjusted leverage & 1984 & 0.0395 & 0.0448 & 1388 & 0.0512 & 0.0564 & 596 & 0.0121 & 0.0178 & $0.0391 * * *$ & $0.0386^{* * *}$ \\
\hline Book-to-market & 1984 & 0.7024 & 0.6203 & 1388 & 0.6934 & 0.5882 & 596 & 0.7233 & 0.6952 & $-0.0299 * *$ & -0.1070 \\
\hline Illiquidity & 1984 & 0.0187 & 0.0159 & 1388 & 0.0139 & 0.0106 & 596 & 0.0298 & 0.0282 & $-0.0159^{* * *}$ & $-0.0176^{* * *}$ \\
\hline Size & 1984 & 5.9800 & 5.6903 & 1388 & 6.7050 & 6.3189 & 596 & 4.2915 & 4.2265 & $2.4135^{* * *}$ & $2.0924^{* * *}$ \\
\hline Number of segments & 1984 & 3.3669 & 3.0000 & 1388 & 3.6070 & 3.0000 & 596 & 2.8077 & 3.0000 & $0.7993^{* * *}$ & 0.0000 \\
\hline Quick ratio & 1984 & 0.5215 & 0.4369 & 1388 & 0.3851 & 0.2668 & 596 & 0.8390 & 0.8331 & $-0.4359^{* * *}$ & $-0.5663^{* * *}$ \\
\hline Foreign sales to net sales & 1984 & 0.3660 & 0.3370 & 1388 & 0.4564 & 0.4817 & 596 & 0.1554 & 0.0000 & $0.3010^{* * *}$ & $0.4817^{* * *}$ \\
\hline Depreciation & 1984 & 0.0341 & 0.0284 & 1388 & 0.0366 & 0.0313 & 596 & 0.0284 & 0.0218 & $0.0082^{* * *}$ & $0.0095^{* * *}$ \\
\hline Return on assets & 1984 & 4.5284 & 4.7956 & 1388 & 4.7944 & 5.1200 & 596 & 3.9090 & 4.0400 & $0.8854^{* * *}$ & $1.0800^{* * *}$ \\
\hline SGA expenses & 1984 & 0.2164 & 0.1629 & 1388 & 0.2390 & 0.1922 & 596 & 0.3001 & 0.2359 & $-0.0886^{* * *}$ & $-0.0406^{* * *}$ \\
\hline Property, plant, and equipment & 1984 & 0.2208 & 0.1813 & 1388 & 0.2433 & 0.2200 & 596 & 0.1683 & 0.0911 & $0.0750^{* * *}$ & $0.1289^{* * *}$ \\
\hline Equity volatility & 1984 & 0.4325 & 0.4214 & 1388 & 0.4155 & 0.4031 & 596 & 0.4720 & 0.4639 & $-0.0565^{* * *}$ & $-0.0608^{* * *}$ \\
\hline Excess Return & 1984 & 0.1632 & 0.1696 & 1388 & 0.1542 & 0.1600 & 596 & 0.1841 & 0.1920 & $-0.0299^{* * *}$ & $-0.0320^{* * *}$ \\
\hline
\end{tabular}


Table A.2

Correlations of firm characteristics

The table reports Pearson product-moment correlation coefficients of firm characteristics. Numbers in italic denote statistical significance at the $1 \%$ level. See also notes to Tables 2 through 4 and 10.

\begin{tabular}{|c|c|c|c|c|c|c|c|c|c|c|c|c|c|c|c|c|c|c|c|c|}
\hline & & (1) & $(2)$ & (3) & (4) & $(5)$ & (6) & $(7)$ & $(8)$ & (9) & $(10)$ & (11) & (12) & (13) & (14) & $(15)$ & $(16)$ & $(17)$ & (18) & (19) \\
\hline Industry-adjusted cost of equity & (1) & 1.0000 & & & & & & & & & & & & & & & & & & \\
\hline Market beta & (2) & 0.4670 & 1.0000 & & & & & & & & & & & & & & & & & \\
\hline SMB beta & (3) & 0.4800 & 0.0874 & 1.0000 & & & & & & & & & & & & & & & & \\
\hline HML beta & (4) & 0.4812 & 0.0820 & 0.0778 & 1.0000 & & & & & & & & & & & & & & & \\
\hline Industry-adjusted leverage & (5) & 0.0770 & 0.0424 & 0.0449 & 0.0655 & 1.0000 & & & & & & & & & & & & & & \\
\hline Book-to-market & (6) & 0.0950 & 0.0379 & -0.2693 & 0.0598 & 0.0737 & 1.0000 & & & & & & & & & & & & & \\
\hline Illiquidity & (7) & 0.0410 & 0.0806 & -0.0641 & -0.1309 & -0.0976 & 0.2191 & 1.0000 & & & & & & & & & & & & \\
\hline Size & (8) & -0.0289 & -0.0533 & -0.0605 & -0.0677 & 0.1647 & -0.0332 & -0.2829 & 1.0000 & & & & & & & & & & & \\
\hline Number of segments & (9) & -0.0045 & -0.0203 & -0.0316 & -0.0545 & -0.0566 & 0.0291 & -0.0752 & 0.4871 & 1.0000 & & & & & & & & & & \\
\hline Quick ratio & (10) & -0.0128 & 0.0142 & 0.0325 & -0.0699 & -0.2341 & -0.0317 & -0.0111 & -0.1980 & -0.1180 & 1.0000 & & & & & & & & & \\
\hline Foreign sales to net sales & (11) & -0.0083 & -0.0529 & 0.0501 & -0.0289 & 0.0634 & 0.0064 & -0.1522 & 0.4264 & 0.1848 & -0.0820 & 1.0000 & & & & & & & & \\
\hline Depreciation & (12) & -0.0179 & 0.0187 & $\begin{array}{r}.0 .0298 \\
-0.0298\end{array}$ & -0.0589 & $\begin{array}{r}-0.0766 \\
-076\end{array}$ & 0.0666 & 0.0377 & 0.1356 & 0.1066 & -0.1573 & -0.0209 & 1.0000 & & & & & & & \\
\hline Return & (13) & -0.0 & -0.0934 & 0.1 & -0.0050 & -0.0110 & -0.1712 & -0.1362 & 0.1572 & 0.0218 & -0.0672 & 0.0998 & -0.0679 & 1.0000 & & & & & & \\
\hline SGA e & (14) & -0.0035 & 0.0274 & 0.0197 & 0.0318 & -0.1382 & -0.1524 & -0.0726 & -0.2796 & -0.1525 & 0.0209 & $\begin{array}{r}-0.0568 \\
-0.058\end{array}$ & 0.0262 & -0.0447 & 1.0000 & & & & & \\
\hline Property, plant, and equipment & (15) & -0.0259 & -0.0278 & -0.0182 & -0.0884 & 0.2579 & 0.0972 & 0.0313 & 0.2988 & 0.1709 & -0.1647 & -0.0258 & 0.6114 & 0.0752 & -0.2108 & 1.0000 & & & & \\
\hline Equity volatility & $(16)$ & 0.0653 & 0.0469 & -0.2207 & 0.0886 & -0.0788 & 0.1588 & -0.1952 & -0.4100 & -0.1642 & 0.1802 & -0.1504 & -0.1080 & -0.3066 & 0.0668 & -0.2546 & 1.0000 & & & \\
\hline Excess return & (17) & -0.0492 & 0. & 0.5264 & 0. & -0.0584 & -0.3413 & -0.0019 & -0.0366 & -0.0293 & 0.0403 & -0.0049 & -0.0163 & 0.1835 & 0.0239 & -0.0426 & 0.0414 & 1.0000 & & \\
\hline 1-year EDF & (18) & 0.0227 & 0.1086 & 0.1682 & 0.0130 & 0.1414 & 0.3597 & 0.2346 & -0.2108 & -0.0567 & -0.0526 & -0.0740 & -0.0472 & -0.3056 & 0.0287 & -0.0683 & 0.4524 & -0.1853 & 000 & \\
\hline 5-year EDF & (19) & 0.0174 & 0.1083 & 0.1842 & 0.0083 & 0.1515 & 0.3957 & 0.2403 & -0.2366 & -0.0751 & -0.0525 & -0.0876 & -0.0658 & -0.3324 & -0.0348 & -0.0618 & $\begin{array}{l}0.4786 \\
0\end{array}$ & -0.1996 & 0.9744 & 6000 \\
\hline
\end{tabular}


Table A.3

Univariate comparison of derivatives users and non-users: Cost of equity computed using weekly returns

The table reports mean and median values of the cost of equity, industry-adjusted cost of equity, and market, small-minus-big (SMB), and high-minus-low (HML) factor betas for a sample of derivatives user and non-user German non-financial firms. The setup is the same as in Table 2 except that weekly returns are used to compute the cost of equity of a firm. See also notes to Table 2.

\begin{tabular}{|c|c|c|c|c|c|c|c|c|c|c|c|}
\hline \multirow[t]{2}{*}{ Variable } & \multicolumn{3}{|c|}{ All firms } & \multicolumn{3}{|c|}{ Derivatives users } & \multicolumn{3}{|c|}{ Derivatives non-users } & \multicolumn{2}{|c|}{ Difference tests } \\
\hline & $\mathrm{N}$ & Mean & Median & $\mathrm{N}$ & Mean & Median & $\mathrm{N}$ & Mean & Median & $\begin{array}{l}\text { Mean } \\
t \text {-test }\end{array}$ & $\begin{array}{l}\text { Median } \\
\text { Wilcoxon test }\end{array}$ \\
\hline Cost of equity & 1984 & 0.0837 & 0.0838 & 1388 & 0.0747 & 0.0743 & 596 & 0.1048 & 0.1059 & $-0.0301 * * *$ & $-0.0317^{* * *}$ \\
\hline Market beta & 1984 & 0.9032 & 0.9378 & 1388 & 0.8107 & 0.8299 & 596 & 1.1187 & 1.1892 & $-0.3080^{* *}$ & $-0.3593^{* * *}$ \\
\hline SMB beta & 1984 & 0.6164 & 0.5646 & 1388 & 0.5106 & 0.4551 & 596 & 0.8629 & 0.8197 & $-0.3523^{* * *}$ & $-0.3646^{* *}$ \\
\hline HML beta & 1984 & 0.3413 & 0.3399 & 1388 & 0.3207 & 0.3259 & 596 & 0.3893 & 0.3725 & $-0.0686^{* * *}$ & $-0.0466^{* *}$ \\
\hline
\end{tabular}


Table A.4

Pooled OLS regressions: Cost of equity computed using weekly returns

The table reports the pooled ordinary least squares (OLS) regression results of the relation between a sample of German non-financial firms' industry-adjusted cost of equity and their use of derivatives. The setup is the same as in Table 3 except that weekly returns are used to compute the cost of equity of a firm. See also notes to Table 3.

\begin{tabular}{|c|c|c|}
\hline & Model 1 & Model 2 \\
\hline Intercept & $\begin{array}{l}0.0257^{* * *} \\
(0.0063)\end{array}$ & $\begin{array}{l}0.0283^{* * *} \\
(0.0069)\end{array}$ \\
\hline Derivatives use & $\begin{array}{l}-0.0154^{* * *} \\
(0.0029)\end{array}$ & $\begin{array}{l}-0.0140^{* * *} \\
(0.0029)\end{array}$ \\
\hline Industry-adjusted leverage & $\begin{array}{l}0.0487^{* * *} \\
(0.0034)\end{array}$ & $\begin{array}{l}0.0559 * * * \\
(0.0041)\end{array}$ \\
\hline Book-to-market & $\begin{array}{l}0.0695^{* * *} \\
(0.0089)\end{array}$ & $\begin{array}{l}0.0637^{* * *} \\
(0.0094)\end{array}$ \\
\hline Illiquidity & $\begin{array}{l}0.0456^{* * *} \\
(0.0082)\end{array}$ & $\begin{array}{l}0.0401^{* * *} \\
(0.0081)\end{array}$ \\
\hline Size & $\begin{array}{l}-0.0376^{* * *} \\
(0.0083)\end{array}$ & $\begin{array}{l}-0.0362^{* * *} \\
(0.0079)\end{array}$ \\
\hline Number of segments & $\begin{array}{l}-0.0031 \\
(0.0019)\end{array}$ & $\begin{array}{l}-0.0034 \\
(0.0019)\end{array}$ \\
\hline Ownership30 & & $\begin{array}{l}-0.0073 \\
(0.0097)\end{array}$ \\
\hline Ownership $30^{+}$ & & $\begin{array}{l}-0.0177^{* * *} \\
(0.0054)\end{array}$ \\
\hline Number of observations & 1855 & \\
\hline Number of derivatives users & 1331 & \\
\hline Number of derivatives non-users & 524 & \\
\hline Adjusted $R^{2}$ & 0.0439 & 0.0540 \\
\hline
\end{tabular}

